\title{
Modeling Habitat Associations for the Common Loon (Gavia immer) at Multiple Scales in Northeastern North America
}

\section{Modélisation des relations du Plongeon huard (Gavia immer) avec l'habitat à différentes échelles dans le nord-est de l'Amérique du Nord}

\author{
$\underline{\text { Anne Kuhn }}^{1}, \underline{\text { Jane Copeland }}^{2}, \underline{\text { John Cooley }}^{3}, \underline{\text { Harry Vogel }}^{3}, \underline{\text { Kate Taylor }}^{4}, \underline{\text { Diane Nacci }}^{1}$, and \\ Peter August
}

\begin{abstract}
Common Loon (Gavia immer) is considered an emblematic and ecologically important example of aquatic-dependent wildlife in North America. The northern breeding range of Common Loon has contracted over the last century as a result of habitat degradation from human disturbance and lakeshore development. We focused on the state of New Hampshire, USA, where a long-term monitoring program conducted by the Loon Preservation Committee has been collecting biological data on Common Loon since 1976. The Common Loon population in New Hampshire is distributed throughout the state across a wide range of lake-specific habitats, water quality conditions, and levels of human disturbance. We used a multiscale approach to evaluate the association of Common Loon and breeding habitat within three natural physiographic ecoregions of New Hampshire. These multiple scales reflect Common Loon-specific extents such as territories, home ranges, and lake-landscape influences. We developed ecoregional multiscale models and compared them to single-scale models to evaluate model performance in distinguishing Common Loon breeding habitat. Based on information-theoretic criteria, there is empirical support for both multiscale and single-scale models across all three ecoregions, warranting a model-averaging approach. Our results suggest that the Common Loon responds to both ecological and anthropogenic factors at multiple scales when selecting breeding sites. These multiscale models can be used to identify and prioritize the conservation of preferred nesting habitat for Common Loon populations.
\end{abstract}

RÉSUMÉ. Le Plongeon huard (Gavia immer) est considéré comme un représentant emblématique et écologiquement important de la faune dépendante du milieu aquatique en Amérique du Nord. L'aire de reproduction du Plongeon huard a subi une contraction depuis le siècle passé en raison de la dégradation de son habitat consécutive au dérangement humain et à l'augmentation de l'occupation humaine sur les bords de lacs. Nous avons choisi le cas du New Hampshire, E.-U., car il y existe un programme de suivi à long terme effectué par le Loon Preservation Committee, qui collige les données biologiques sur l'espèce depuis 1976. La population du Plongeon huard est répartie partout dans cet État, selon une grande variété de milieux lacustres, de conditions de qualité d'eau et de degrés de dérangement humain. Nous avons utilisé une approche multi-échelles afin d'évaluer la relation entre le Plongeon huard et son habitat de nidification, dans trois écorégions physiographiques naturelles au New Hampshire. Ces différentes échelles reflètent d'autres caractéristiques relatives au Plongeon huard, comme les territoires, les domaines vitaux et les influences lac-paysage. Nous avons élaboré des modèles multi-échelles écorégionaux et les avons comparés à des modèles tenant compte d'une seule échelle pour évaluer leur performance à distinguer correctement l'habitat de nidification du Plongeon huard. D'après les critères de la théorie de l'information, les observations empiriques soutiennent les modèles multi-échelles tout comme les modèles à une seule échelle, dans les trois écorégions, résultat qui justifie une approche fondée sur la moyenne des modèles. Nos résultats

${ }^{1}$ U.S. Environmental Protection Agency, Atlantic Ecology Division, ${ }^{2}$ SRA International Inc., ${ }^{3}$ The Loon Preservation Committee, ${ }^{4}$ BioDiversity Research Institute, ${ }^{5}$ University of Rhode Island Department of Natural Resources Coastal Institute in Kingston

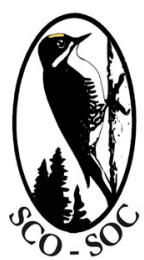

Sponsored by the Society of Canadian Ornithologists and Bird Studies Canada Parrainée par la Société des ornithologistes du Canada et Études d'oiseaux Canada

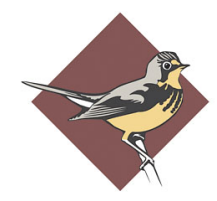
BiRD STUDIES CANADA 
laissent croire qu'au moment de sélectionner son site de nidification, le Plongeon huard réagit tout autant aux facteurs écologiques qu'aux facteurs anthropiques, à différentes échelles. Il est possible d'utiliser ces modèles multi-échelles pour déterminer l'habitat de nidification de prédilection des populations de Plongeon huard et pour en prioriser la conservation.

Key Words: ecoregion; Gavia immer; human disturbance; lake water quality; landscape context; multiscale landscape habitat models

\section{INTRODUCTION}

Habitat loss and alteration have been identified as major causes of endangerment for many species worldwide (Stein and Flack 1997, Wilcove et al. 1998, Johnson 2007). Wildlife habitat models are important management tools for predicting species presence and identifying suitable habitat to inform conservation decisions and priorities (Scott et al. 2002, Austin 2007, Strauss and Biedermann 2007). The integration of landscape and wildlife ecology has led to considerable research focused on describing the influence of landscape pattern on wildlife and how these relationships vary with scale (Thompson and McGarigal 2002, Edwards et al. 2003, Wu 2004, Turner 2005, Li et al. 2006). Much of this research has resulted in a more organismcentered perspective, allowing the focal species to define the scale of analysis (Garshellis 2000, Meyer et al. 2002, Thompson and McGarigal 2002). Recognizing that there is no single correct spatial scale at which to describe species-habitat relationships, multiscale approaches provide important information about how landscape-scale processes influence observed species distribution patterns (Wiens 1989, Riitters et al. 1997, Graf et al. 2005).

In avian ecology, hierarchical patterns and processes are generally believed to be common in both habitats and bird responses to habitats (Gutzwiller and Anderson 1987, Saab 1999, Cushman and McGarigal 2002, 2004, Luck 2002, Kristan and Scott 2006, Lawler and Edwards 2006). A hierarchical approach is warranted and recommended for developing, evaluating, and implementing conservation plans for avian species to provide a broader understanding of avian-habitat associations within a landscape context (Saab 1999, Freemark et al. 2002, Earnst et al. 2006, Thogmartin and Knutson 2007).
Multiscale habitat association studies evaluated at a landscape scale are typically correlative, whereby habitat preferences are inferred by comparing occupied or "use" sites with randomly selected unoccupied or "nonuse" sites across a wide range of spatial scales, varying from individual nest sites to habitat selection across a heterogeneous landscape. The goal of many multiscale habitat studies is to determine how multiple scales of variation combine to produce the observed patterns of species distribution and abundance (Penhollow and Stauffer 2000, Driscoll et al. 2005, Trocki and Paton 2006). Scale-dependent habitat associations and avian responses to scale-dependent patterns in their habitat need to be accurately represented in habitat models to enhance the ecological relevance of these models for management and conservation applications (Graf et al. 2005, Turner 2005, Kristan 2006, Li et al. 2006, Deppe and Rotenberry 2008, Nocera et al. 2008).

A number of multiscale habitat studies have emphasized the need to address the hierarchical structure of habitat variables that are components of other variables in a nested hierarchy (Goldstein 2003, Battin and Lawler 2006, Kristan and Scott 2006, Lawler and Edwards 2006). Kristan (2006) describes two ways in which multiple scales of variation in the environment could result in hierarchical structure in avian-habitat associations: hierarchical structure in habitat, and hierarchical responses by birds to multiple scales of variation in habitat. It is generally thought that when there is hierarchical structure in habitat variables, birdhabitat associations will reflect this hierarchical structure, and habitat models must correctly represent the avian habitat selection process (Kristan 2006). The scales at which avian population studies are conducted can be generally divided into local, landscape and regional; however, they should be ecologically relevant to the focal species. 
Common Loon (Gavia immer), hereafter loon, breeds on freshwater lakes in Iceland, Greenland, and across Canada and the northern United States from early spring through autumn. Common Loon winters along both the Atlantic and Pacific coasts before returning each spring to its natal breeding lakes soon after ice-out. Loons are considered habitat specialists during the breeding season (Evers 2007). They prefer relatively large lakes containing both shallow and deep-water areas. Loons are visual predators and feed mostly on fish, but also on amphibians and invertebrates. Water clarity is an important component of breeding habitat selection, and loons typically prefer lakes with at least 3-4 m visibility (Vermeer 1973, McIntyre 1983, 1988, Blair 1992).

Anthropogenic disturbances that affect loons on the breeding lakes include habitat degradation from shoreline development, encroachment of buildings on traditional nesting sites, decreased water clarity from erosion and surface runoff, nutrient enrichment, increased predator densities, changes in fish species composition, and increased human recreational activity (Titus and VanDruff 1981, Heimberger et al. 1983, Jung 1991, Newbrey et al. 2005, Desorbo et al. 2007, Found et al. 2008). Lake acidification, accidental ingestion of lead fishing tackle, and bioaccumulation of environmental contaminants such as methylmercury are other significant stressors threatening loon productivity and overall fitness (Barr 1986, Alvo et al. 1988, Meyer et al. 1998, Burgess et al. 2005, Kamman et al. 2005, Evers et al. 2008). Common Loon is currently listed as a threatened species in New Hampshire and Michigan and is a species of special concern in Connecticut, Idaho, Massachusetts, Montana, New York, Washington, and Wisconsin (Evers 2007). A conservative estimate of the adult loon population in the northeastern United States is roughly 5250 individuals based on a $5-y r$ average from 2004 to 2008 (Northeast Loon Study Working Group 2008; Fig. 1).

Historical records indicate that throughout northeastern North America there has been a $50 \%$ reduction in loon populations from the early 1900s to the 1970s (McIntyre and Barr 1997). In New England, loon populations declined 35-75\% between 1965 and 1985 (Rimmer 1992, McIntyre and Barr 1997). A northward breeding range contraction has also been documented within the last 100-150 yr, suggesting that loons may be finding less suitable habitat than previously existed
(McIntyre 1988, McIntyre and Barr 1997). The New Hampshire Loon Preservation Committee (LPC) was formed in 1975 as a result of concerns about declines in the presence and productivity of Common Loon in the state. The LPC comprises a network of biologists and volunteers that have been monitoring loon populations and managing their recovery within the state of New Hampshire for > 30 yr (Loon Preservation Committee 2005).

From the 1970s to 2000s, New Hampshire had the largest growth in human population of any state in the nine-state U.S. Northeast region. From 1990 to 2004 , the population growth rate was $17.2 \%$, twice that of the rest of New England (Society for the Protection of New Hampshire Forests 2005). The human population of New Hampshire is expected to grow by 358,000 residents between 2000 and 2025 , an increase of $>28 \%$ (Society for Protection of New Hampshire Forests 2005). The fastest rate of population change is projected to occur in the Lakes Region, where a significant portion of the loon population of New Hampshire resides during breeding season. These projected population growth estimates for New Hampshire highlight the urgency of targeting breeding habitat of the Common Loon for conservation and protection.

Our primary objective was to develop predictive breeding habitat suitability models for Common Loon populations in New Hampshire that include metrics of anthropogenic change and influence as explanatory factors. We hypothesized that the loon is using both ecological and anthropogenic cues when selecting breeding habitat. Our second objective was to assess the effects of scale on habitat associations for breeding loon populations and to compare efficacies of single-scale and multiscale habitat models for describing loon distributions.

\section{METHODS}

\section{Study area}

Demographic data for Common Loon in New Hampshire have been collected by the New Hampshire LPC during the breeding season (May through August) each year since 1976. Field biologists follow a standardized data collection protocol (Taylor and Vogel 2000, Loon Preservation Committee 2004) to document loon presence and abundance, nesting and brooding sites, nesting attempts, nest site and type, and nest success 
Fig. 1. Average number of adult Common Loon in the northeastern United States from 2004 to 2008. Data sources: New York Adirondack Center for Loon Conservation (http://www.briloon.org/science-and conservation/centers/adirondackloons.php), Vermont Center for Ecostudies (2007 breeding status of Common Loon in Vermont, http://www.vtecostudies.org/PDF/Loonreport07\%20final.pdf), New Hampshire Loon Preservation Committee, Maine Audubon Society (The Maine Loon Project, http:// www.maineaudubon.org/conserve/loon/index.shtml), and Massachusetts Department of Conservation and Recreation (http://www.mass.gov/dcr/index.htm).

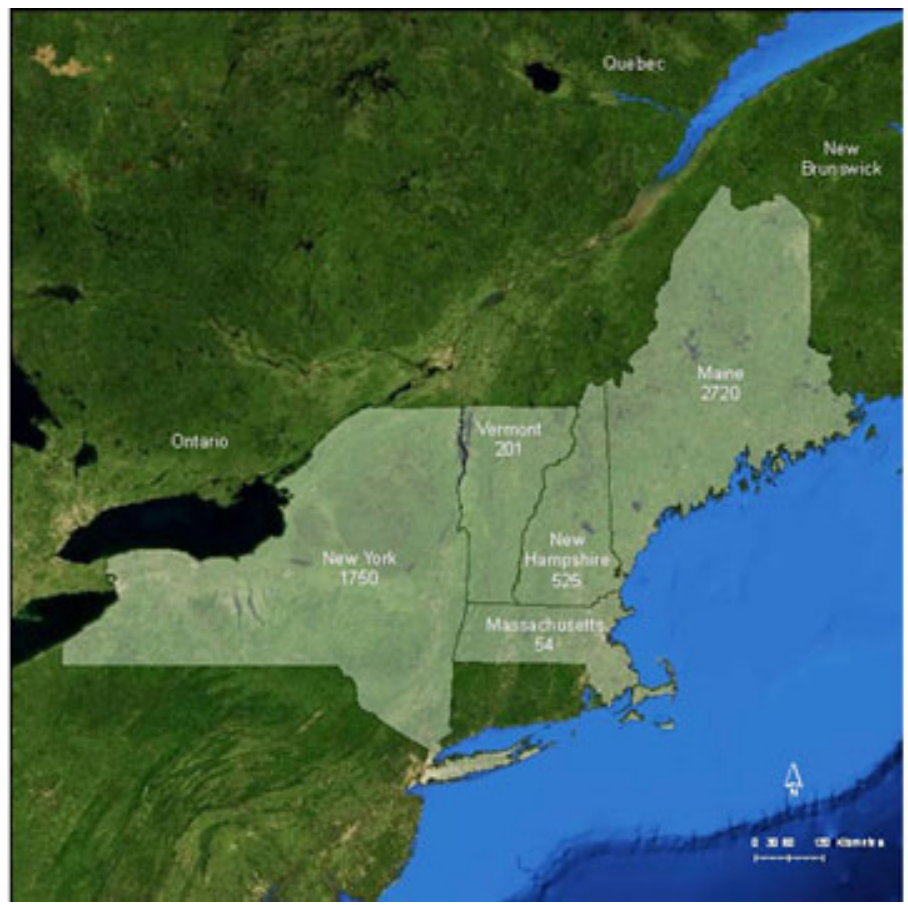

and failure. The LPC monitoring program involves a complete annual census of the entire breeding loon population in the state of New Hampshire, including presence and absence of loons on $>750$ lakes (Fig. 2).

Habitat water quality data were obtained from the New Hampshire Department of Environmental Services (DES) state-wide water quality program that includes 775 lakes (New Hampshire Department of Environmental Services 2005). There are three main physiographic ecoregions in New Hampshire $\left(42^{\circ} 40^{\prime}-{ }^{\circ} 18^{\prime}\right.$ N, $70^{\circ} 37^{\prime}-72^{\circ} \mathrm{W}$ ) based on broad geological, climatic, and landform characteristics: ecoregion 1, Northern White Mountain; ecoregion 2, New Hampshire-Vermont Upland; and ecoregion 3, Southern New England Coastal Hills and Plain (Sperduto and Nichols 2004; Fig. 2). The LPC uses these ecoregions along with an estimated maximum loon dispersal distance of
$20 \mathrm{~km}$ (Evers 2001) to divide the New Hampshire Common Loon population into subpopulations for management purposes.

We used these three physiographic classifications as the broadest scale for analysis, with increasingly finer scales within each of the ecoregions. Multiple scales reflecting loon-specific ecologically relevant extents such as Common Loon territories, home ranges, and lake-landscape influences within each of these ecoregions were chosen for our assessment. Multiscale habitat models were developed using the occurrence (presence and absence) of breeding Common Loon on lakes within each of the ecoregions (Table 1). Analyses were nested within the three physiographic ecoregions, with each ecoregion spanning $>160 \mathrm{~km}$ from north to south and ranging from approximately $40-60 \mathrm{~km}$ east to west (Table 1, Fig. 2). 
Fig. 2. Land cover map for the State of New Hampshire, indicating ecological sections (ecoregions), the distribution of lakes, and Common Loon nest site locations.

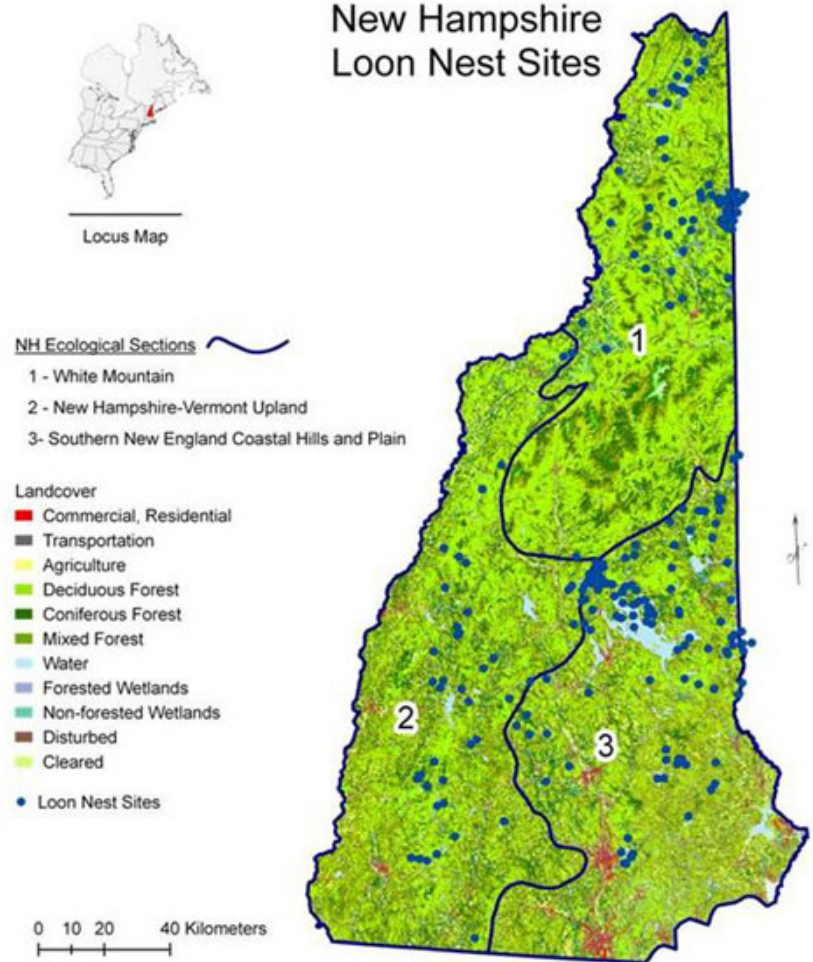

\section{Spatial scales}

Spatial scale is described by grain size and spatial extent (Wiens 1989, 2002). Grain is the resolution or minimum mapping unit of the data, whereas extent is the size of a mapped area. Grain and extent have ecological relevance for organisms, for example, the smallest size of habitat element that a species can resolve (Freemark et al. 2002). We used a lake-landscape context to characterize the spatial structure of lake variation by varying the spatial extent surrounding each lake from local to regional scale (Soranno et al. 2009). We examined four biologically relevant spatial scales within each ecoregion: catchment scale, riparian scale, foraging scale, and nesting scale. Catchment scale includes the landscape features influencing habitat and water quality within $500 \mathrm{~m}$ of a lake. Riparian scale measures landscape features within $150 \mathrm{~m}$ of the lake shoreline (Johnston and Shmagin 2006, Martin and Soranno 2006, Fraterrigo and Downing 2008). Loon home range is limited to the breeding territory, with mean size ranging from 6-8 ha to up to 200 ha (Meyer and Woodford 1996, McIntyre and Barr 1997), depending on lake size, territory type (whole, partial, or multiple lakes), and number of loon pairs on larger lakes. The foraging scale, or estimated home range, of breeding loons encompassed habitat features within a 500-m radius of the nest location (approximately $78 \mathrm{ha}$ ). The finest scale, the nesting scale, or breeding territory, measures habitat within a $150-\mathrm{m}$ radius of the nest location (approximately 7 ha; Fig. 3). This distance was chosen because previous research demonstrated a negative relationship in chick survival with presence of lakeshore cottage development within $150 \mathrm{~m}$ of Common Loon nest sites (Heimberger et al. 1983, Strong and Bissonette 1989). Features from each of these four scales were measured on lakes where loon occurrence has been monitored regularly.

Common Loon nest site locations were recorded in the field using GPS units with accuracy of at least $10 \mathrm{~m}$ and mapped in GIS using ArcInfo version 9.1 
Table 1. Monitored frequency of occurrence of breeding Common Loon in three New Hampshire physiographic ecoregions.

\begin{tabular}{lccc}
\hline \hline & & \multicolumn{2}{c}{ Territorial Common Loon } \\
\cline { 3 - 4 } Ecoregion & Number of lakes monitored & Present & Absent \\
\hline 1, Northern White Mountain & 59 & 44 & 15 \\
2, New Hampshire-Vermont Upland & 130 & 58 & 72 \\
3, Southern New England Coastal Hills and Plain & 133 & 79 & 54 \\
Statewide combined multiscale model & 322 & 181 & 141 \\
\hline
\end{tabular}

software (Environmental Systems Research Institute 2009).

\section{Environmental variables}

Based on discussions with Common Loon field experts from the LPC and on published habitat information, a suite of environmental habitat variables were considered for inclusion in a priori models to describe breeding loon habitat preferences. Twenty-one variables (Table 2) were measured for 322 lakes that were consistently monitored from 1995 through 2006 by the LPC (Table 1). The variables chosen are thought to have biological relevance for loons by directly or indirectly influencing habitat associations and preferences. Habitat data were acquired from the New Hampshire state GIS databases (NH GRANIT: http://www.granit.unh.edu/). The most recent water quality values for each lake were obtained from the New Hampshire DES lake monitoring program (New Hampshire Department of Environmental Services 2005). The $2001 \mathrm{New}$ Hampshire land cover data (30-m cell size, 2001) represent 23 land cover classes that we aggregated and re-classified to seven land cover types following an Anderson Level I classification system (Anderson et al. 1976; Table 2). The proportions of each land cover class and road data (1:24000 scale, 2005) were assessed within 150- and 500-m zones around each lake.

The LPC monitoring program requires a minimum of three visits to each lake during the breeding season and repeated visits to lakes over multiple years. The large size $(2.7-6.3 \mathrm{~kg})$ and aggressive and conspicuous territorial behavior of loons results in high detection probability (Hammond 2008). Therefore, monitoring data were not adjusted for false absences (MacKenzie et al. 2003, Tyre et al. 2003, Stauffer et al. 2004, MacKenzie 2005). Nonnesting sites were randomly located on the 141 lakes that had been monitored multiple times over at least one decade but where loons were never observed. These verified absence lakes were at least 10 ha in size, which is generally considered a minimum for Common Loon habitat suitability (Evers 2007). We used verified absence lakes for random non-nesting sites instead of using unoccupied portions of lakes occupied by loons to avoid violating statistical assumptions of independence and because of the loon's highly territorial behavior during the breeding season. We developed a GIS program to randomly locate a non-nesting point along an absence lake's perimeter. The program allows for the possibility that the random non-nest point may be placed on an island shoreline (Fig. 4). GIS buffering tools were then used to quantify the land cover and road density within 150- and 500-m radii surrounding the nest and random non-nest locations (Fig. 3). There was no overlap among nest or nonnest site locations for any of the radius regions.

The minimum distance from the nest or non-nest point location to the nearest human population center was computed to evaluate potential effects of human disturbance. This metric provides a measure of a nest's or non-nest's proximity to highdensity residential development and municipal community centers (defined by New Hampshire Department of Environmental Services 2006). Other lake-specific variables that were evaluated as 
Fig. 3. Maps illustrating land cover and road density within 150- and 500-m zones of each lake and within 150- and 500-m radii of a Common Loon nest site and a randomly chosen, non-nest site. Red and blue lines represent the 150- and 500-m radii areas, respectively, surrounding each nest and non-nest site. Purple and black lines represent the 150- and 500-m zones, respectively, surrounding each lake.
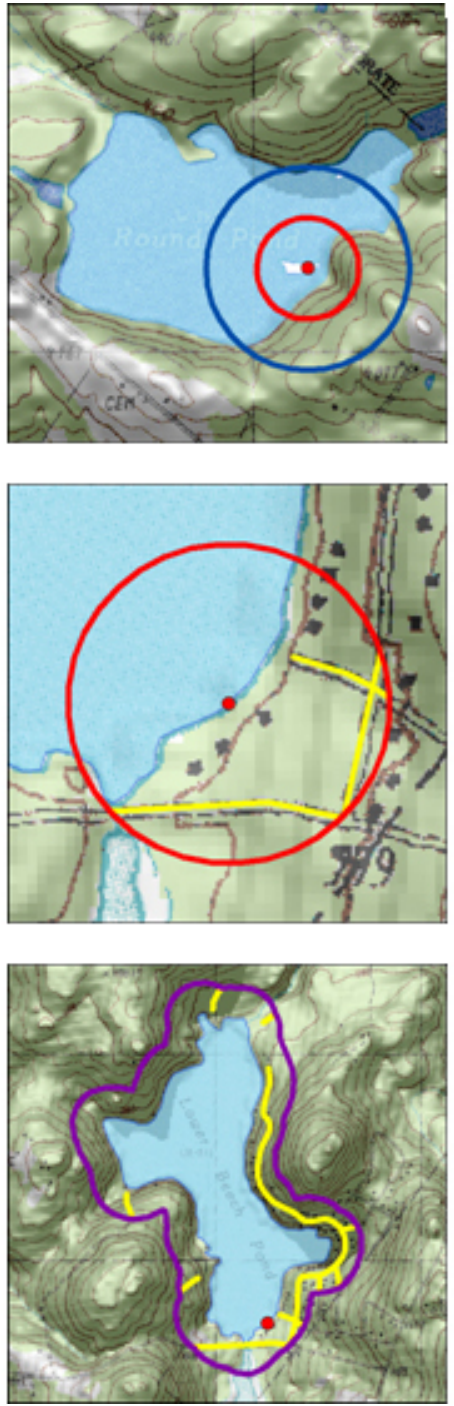
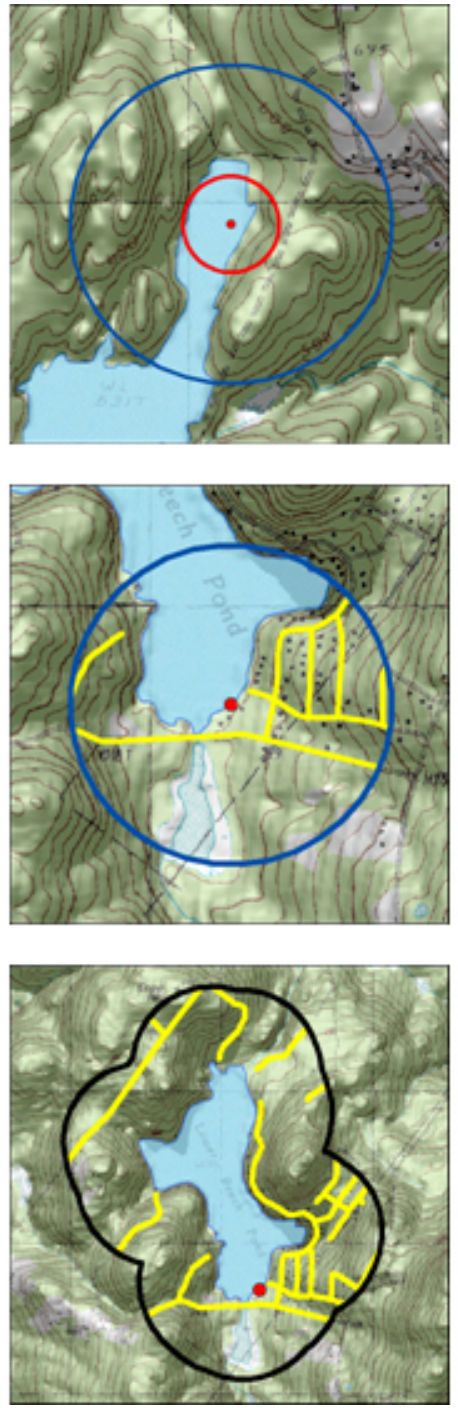

indicators of human activity included total phosphorus, conductivity, and water clarity (Table 2). Each of these is associated with the cultural eutrophication of lakes (Johnston and Shmagin 2006, Murtagh and Pooler 2006).

Lake occupancy appears to be spatially correlated (Piper et al. 2006, Kuhn-Hines 2008). Two distance metrics were developed to reflect this behavior: one was the distance to the closest lake and the other was the distance to the closest lake with Common Loon present (Table 2, Fig. 5). Loons also prefer nesting in quiet, protective coves found along convoluted shorelines (Vermeer 1973, McIntyre 1983, 1988). Lake perimeter and lake area were used to develop a lake shape index (shoreline development index) that describes the irregularity of the shoreline (Hutchinson 1957, Patton 1975, McGarigal and Marks 1995, Meyer 2006). Lake shape was calculated as a ratio of shore length to 
Table 2. Summary of explanatory variables for breeding Common Loon presence and absence lakes across New Hampshire. $N=322$ lakes. Means were measured for the $150-\mathrm{m}$ zone surrounding each lake. All variables are included to highlight the range of variables considered during the modeling process. We modeled only variables indicated as included at each of the four scales within each ecoregion and statewide.

\begin{tabular}{|c|c|c|c|c|}
\hline \multirow[b]{2}{*}{ Habitat variable } & \multirow[b]{2}{*}{ Description } & \multicolumn{2}{|c|}{ Mean (SD) } & \multirow[b]{2}{*}{ Reason for inclusion/exclusion } \\
\hline & & Presence & Absence & \\
\hline Lake area & Lake surface area, excluding islands (ha) & 209 (1125) & $33(34)$ & $\begin{array}{l}\text { Included: loons prefer larger lakes for a } \\
\text { variety of reasons }\end{array}$ \\
\hline Lake perimeter & Lake shoreline length $(\mathrm{km})$ & $11(23)$ & $4(3)$ & Excluded: correlated with lake area \\
\hline Lake shape & $\begin{array}{l}\text { Lake configuration and shoreline } \\
\text { complexity }\end{array}$ & $2(1)$ & $2(1)$ & $\begin{array}{l}\text { Excluded: correlated with lake area and } \\
\text { perimeter }\end{array}$ \\
\hline Maximum depth & Maximum lake depth (m) & $14(11)$ & $6(4)$ & Included: important for fish/prey habitat \\
\hline Islands & Number of islands per lake & $4(13)$ & $1(2)$ & $\begin{array}{l}\text { Included: loons prefer small islands for } \\
\text { nesting }\end{array}$ \\
\hline Elevation & Lake elevation (m) & $296(154)$ & $251(152)$ & $\begin{array}{l}\text { Included: estimate of geographic } \\
\text { specification }\end{array}$ \\
\hline Lake flushing rate & $\begin{array}{l}\text { Total volume of water entering a lake } \\
\text { per unit time }\left(\mathrm{m}^{3} / \mathrm{yr}\right) \text { divided by lake } \\
\text { volume }\left(\mathrm{m}^{3}\right)\end{array}$ & $12(43)$ & $39(82)$ & $\begin{array}{l}\text { Included: important factor in nest } \\
\text { survivorship }\end{array}$ \\
\hline Water clarity & Secchi depth transparency reading $(\mathrm{m})$ & $4.5(2.1)$ & $2.6(1.2)$ & Included: loons are visual predators \\
\hline Total phosphorous & $\begin{array}{l}\text { Organic and inorganic forms of } \\
\text { phosphorus }(\mathrm{mg} / \mathrm{L})\end{array}$ & $\begin{array}{c}0.009 \\
(0.005)\end{array}$ & $\begin{array}{c}0.017 \\
(0.011)\end{array}$ & Included: estimate of human disturbance \\
\hline $\mathrm{pH}$ & $\begin{array}{l}\text { Hydrogen ions in the water or acidity } \\
\text { (units) }\end{array}$ & $6.6(0.4)$ & $6.4(0.6)$ & Included: indicator of fish habitat \\
\hline Trophic status & $\begin{array}{l}\text { Categorical: } 1=\text { oligotrophic, } 5= \\
\text { mesotrophic, } 10=\text { eutrophic }\end{array}$ & $3(3)$ & $6(3)$ & Excluded: correlated with phosphorous \\
\hline Conductivity & $\begin{array}{l}\text { Number of ionic particles present }(\mu \\
\text { mhos } / \mathrm{cm})\end{array}$ & $48(33)$ & $66(53)$ & Excluded: negatively correlated with clarity \\
\hline $\begin{array}{l}\text { Loon distance } \\
\text { metrics }\end{array}$ & $\begin{array}{l}\text { Distance to nearest loon presence lake } \\
\text { (upper numbers) and distance to nearest } \\
\text { loon absence lake (lower numbers, km) }\end{array}$ & $\begin{array}{l}2(2.4) \\
6(4.5)\end{array}$ & $\begin{array}{l}5(5.2) \\
5(4.2)\end{array}$ & $\begin{array}{l}\text { Included: hypothesized loon dispersal } \\
\text { factor }\end{array}$ \\
\hline $\begin{array}{l}\text { Developed- } \\
\text { residential/urban }\end{array}$ & $\begin{array}{l}\text { Proportion of residential and urban } \\
\text { developed land within } 150-\text { and } 500-\mathrm{m} \\
\text { zones surrounding each lake and nest/ } \\
\text { non-nest site }(\%)\end{array}$ & $3(4)$ & $4(7)$ & Included: estimate of human disturbance \\
\hline Agriculture & $\begin{array}{l}\text { Proportion of pasture, hay, and } \\
\text { cultivated cropland cover within } 150- \\
\text { and } 500-\mathrm{m} \text { zones surrounding each lake } \\
\text { and nest/non-nest site }(\%)\end{array}$ & $1(2)$ & $2(3)$ & Included: estimate of human disturbance \\
\hline Forested & $\begin{array}{l}\text { Proportion of forested land cover within } \\
150-\text { and } 500-m \text { zones surrounding each } \\
\text { lake and nest/non-nest site }(\%)\end{array}$ & $36(13)$ & $45(17)$ & Included: hypothesized habitat factor \\
\hline
\end{tabular}




\begin{tabular}{|c|c|c|c|c|}
\hline Wetland & $\begin{array}{l}\text { Proportion of forested and nonforested } \\
\text { wetland cover within } 150 \text { - and } 500-\mathrm{m} \\
\text { zones surrounding each lake and nest/ } \\
\text { non-nest site }(\%)\end{array}$ & $4(7)$ & $10(13)$ & Included: hypothesized habitat factor \\
\hline Open water & $\begin{array}{l}\text { Proportion of open water with }<25 \% \\
\text { vegetation or soil within } 150 \text { - and } 500-\mathrm{m} \\
\text { zones surrounding each lake and nest/ } \\
\text { non-nest site }(\%)\end{array}$ & $54(12)$ & $35(13)$ & Included: hypothesized habitat factor \\
\hline Cleared and disturbed & $\begin{array}{l}\text { Proportion of cleared or disturbed land } \\
\text { within } 150-\text { and } 500-\mathrm{m} \text { zones } \\
\text { surrounding each lake and nest/non-nest } \\
\text { site }(\%)\end{array}$ & $3(4)$ & $4(6)$ & Excluded: correlated with Developed \\
\hline Road density & $\begin{array}{l}\text { Density of roads within } 150 \text { - and } 500-\mathrm{m} \\
\text { zones surrounding each lake and nest/ } \\
\text { non-nest site }\left(\mathrm{m} / \mathrm{m}^{2}\right)\end{array}$ & $\begin{array}{c}1798 \\
(1255)\end{array}$ & $\begin{array}{c}2132 \\
(1759)\end{array}$ & Included: estimate of human disturbance \\
\hline $\begin{array}{l}\text { Minimum distance to } \\
\text { human population } \\
\text { center }\end{array}$ & $\begin{array}{l}\text { Minimum distance to high-density } \\
\text { residential areas and municipal } \\
\text { community centers from nest/non-nest } \\
\text { site }(\mathrm{km})\end{array}$ & $4(4)$ & $3(3)$ & Included: estimate of human disturbance \\
\hline
\end{tabular}

the circumference of a circle with the same area as the lake (Table 2). All GIS metrics were computed using ArcInfo version 9.1 (Environmental Systems Research Institute 2009).

\section{Single- and multiscale habitat model development}

We developed Common Loon breeding habitat suitability index (HSI) models for each spatial scale within each of the ecoregions and for all lakes combined for a set of statewide models $(n=322)$. Prior to model development, we screened explanatory variables within each spatial scale for strong correlations because multicollinearity of independent explanatory variables can cause problems in logistic regression models (Menard 2002). Explanatory variables used to build the single and multiscale models were checked for multicollinearity using Pearson's correlation matrix and variance inflation factors (VIFs). We included only covariates that were not highly correlated $(\mid r$ $\mid<0.6)$ and made sure that explanatory variables displayed VIFs < 10 (Graham 2003, O'Brien 2007; Table 2).

We used an information theoretic approach for model development and assessment. We followed the common practice of developing a general global model, i.e., the most complex model of the set of plausible models, using logistic regression and maximum likelihood estimation, to describe loon nesting habitat at the broadest scale (statewide) and for each ecoregion, and then creating alternative models as nested subsets of the global model (Burnham and Anderson 2002). For ease of model interpretation and application, we modeled only additive terms and did not consider interaction terms. We then used various criteria to select the most parsimonious models based on nested subsets of the habitat variables in the global model that were associated with nesting territories at each scale. The model-fitting statistics included results from maximum likelihood analyses such as the deviance $(-2 \log \mathrm{L})$ and the max-rescaled $\mathrm{R}^{2}$ for each of the competing models (Agresti 1996, Hosmer and Lemeshow 2000). Max-rescaled $\mathrm{R}^{2}$ is a likelihoodbased measure of the strength of association between the dichotomous dependent variable (e.g., Common Loon nest presence) and the explanatory variables (Cox and Snell 1989, Estrella 1998, Heinz et al. 2005).

The corrected Akaike Information Criterion for small sample size $\left(\mathrm{AIC}_{\mathrm{c}}\right)$ was used to evaluate the relative strength of competing plausible models (Burnham and Anderson 2002) within each spatial scale within each region. An information criterion estimates the amount of information lost when using a particular model compared with other possible models. Better models lose less information (Burnham and Anderson 2002). AIC $_{c}$ values can only be used to compare models when the response variable data sets are exactly the same; therefore, it is only appropriate to compare competing models 
Fig. 4. Maps illustrating how, using GIS, route feature classes were generated along the perimeter of each lake so that all features of a lake, including islands, are treated as a single entity. Along each route, a randomly chosen non-nest site was located on lakes that were monitored for loons but had no loon occurrences.

\section{Route Feature Class}

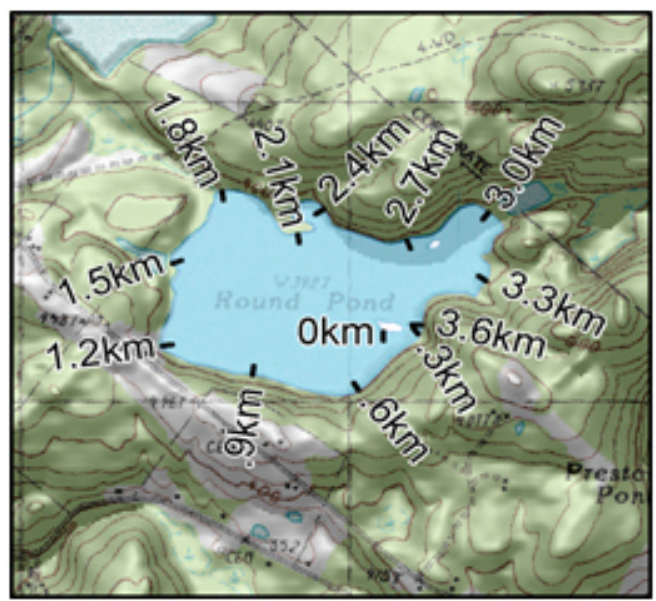

\section{Random Nest Location}

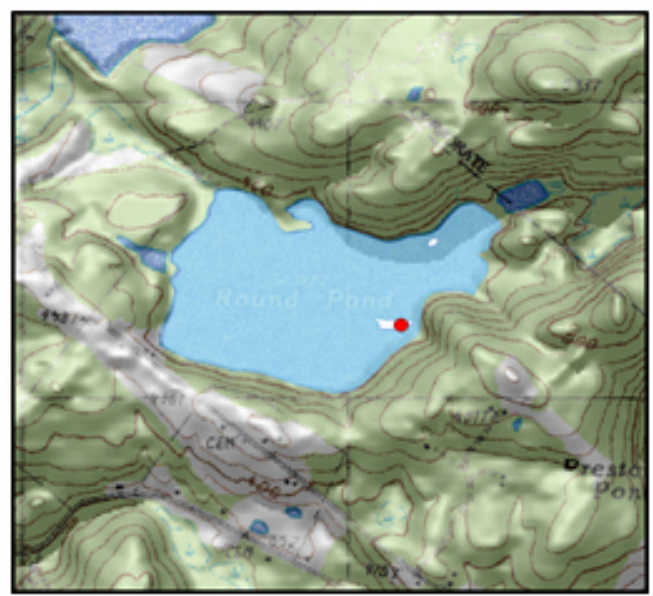

within each region. The model with the lowest $\mathrm{AIC}_{\mathrm{c}}$ value of a set of candidate models is considered the best approximating model, i.e., the most parsimonious model that achieves a balance between bias and variance (Burnham and Anderson 2002).

The explanatory variables in the best approximating models at each single spatial scale were then used to build a multiscale habitat model (Graf et al. 2005, Lawler and Edwards 2006) for each ecoregion and for a statewide multiscale model. The difference between the $\mathrm{AIC}_{\mathrm{c}}$ of a given model and the minimum $\mathrm{AIC}_{\mathrm{c}}$ of the candidate set $\left(\Delta_{\mathrm{i}} \mathrm{AIC}_{\mathrm{c}}\right)$ and $\mathrm{AIC}_{\mathrm{c}}$ weights, $w_{\mathrm{i}}$ (the weight of evidence in favor of a given model relative to the set of candidate models), were used to rank the models within each ecoregion (Burnham and Anderson 2002, Anderson 2008). When it is not clear which of the models from the set of candidate models is best, as measured by $\mathrm{AIC}_{\mathrm{c}} w_{\mathrm{i}}$ (i.e., $w_{\mathrm{i}}>0.9$ for any given model), an information theoretic-based model average approach is warranted. In this case, each of the candidate models with substantial empirical support (i.e., $\left.\Delta_{\mathrm{i}} \mathrm{AIC}_{\mathrm{c}} \leq 2\right)$ was weighted by its Akaike weight and combined into a single, averaged model by generating weighted parameter estimates (i.e., parameter estimate multiplied by $w_{\mathrm{i}}$ and then summed across all models) for each parameter, making an "averaged" prediction from the combined model (Burnham and Anderson 2002, Hollister et al. 2008). Parameter estimates obtained by model averaging reduce model selection bias and account for model selection uncertainty (Johnson and Omland 2004).

We used odds ratios to examine the magnitude of the effect of an explanatory variable on the probability of Common Loon nest presence at fixed values of other variables. The odds ratio represents the change in odds of observing loon nest presence for a unit change in the explanatory variable. The odds ratio of an explanatory variable is calculated as $\mathrm{e}^{(\mathrm{b} \times \text { unit change) }}$, where $b$ is the parameter's coefficient in the multivariable model, and the test of whether $b>0$ is equivalent to testing whether the confidence interval of the odds ratio crosses 1.0 (Earnst et al. 2006).

Once the most parsimonious models for each data set were chosen, we used classification tables to assess the accuracy of habitat models (Fielding and 
Fig. 5. Development of minimum Euclidian distance measured from the edge of a lake to the edge of the nearest lake with and without loons using GIS.
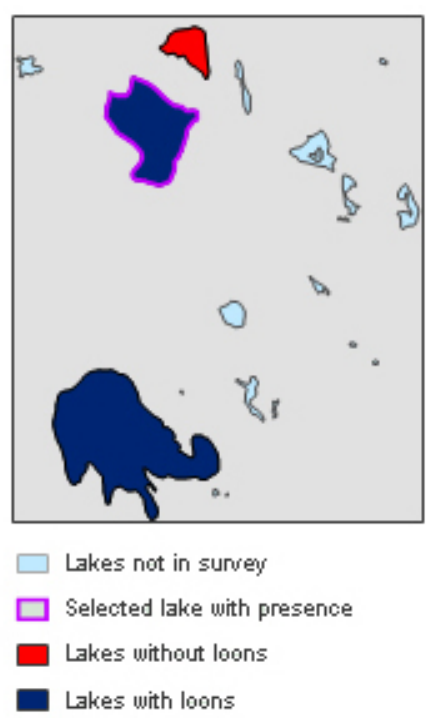

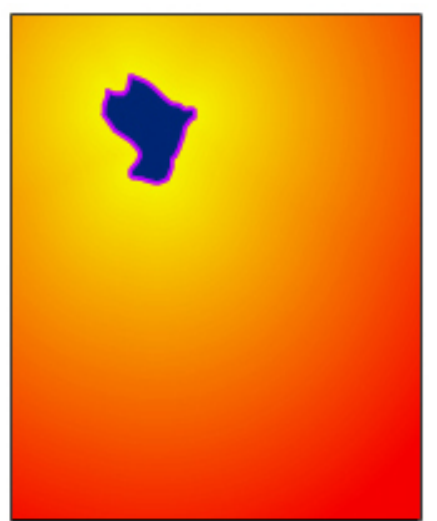

Distance

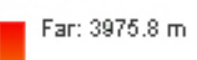

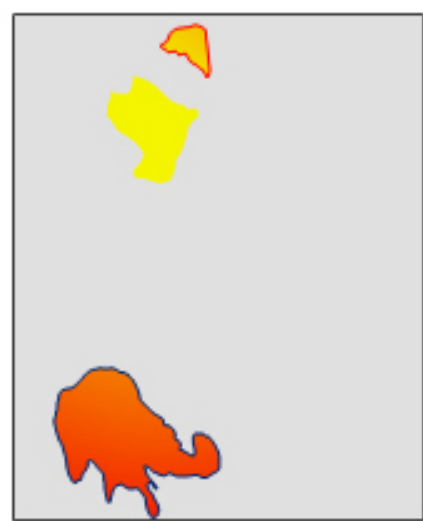

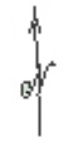

Select lake with Loon

Create distance grid from lake edge

Intersect distance grid with loon

presence and absence
Bell 1997). The area under the curve statistic (AUC) was derived from the receiver operating characteristics (ROC) curve and was calculated for each model as an additional measure of model performance. AUC values range from 0.5 (scores for presence/absence do not differ: poor classifier) to 1.0 (complete distinction of presence from absence: perfect classifier). For example, an AUC of 0.88 means that a randomly chosen case from the presence group will have a greater classifier score than a random selection from the absence group with a probability of 0.88 (Fielding and Bell 1997, Graf et al. 2005, Hames et al. 2006).

Residual analyses of the final fitted models were used to test for spatial autocorrelation using the Moran's Index method (Moran 1950, Fortin and Dale 2005). The Pearson residuals from the fitted probability (HSI) for each lake and its geographic coordinates were used to assess spatial autocorrelation in the final models. Statistical analyses were performed using the software packages SAS 9.1 (SAS Institute Inc. 2003), SPSS 12.0 (SPSS Inc. 1999) and GS+ Geostatistics for Environmental Sciences (Gamma Design Software 2001).

\section{RESULTS}

Comparing general summary statistics for Common Loon presence and absence at lakes across the entire state of New Hampshire highlighted variables associated with loon habitat preferences (Table 2). Loons were found on lakes that were larger, deeper, and clearer, with more islands, and shoreline perimeter closer to nearby lakes inhabited by other loons. Loons also selected lakes with reduced conductivity and total phosphorus, higher $\mathrm{pH}$, at higher elevations with lower flushing rates, and further away from human community centers. Land cover within the $150-\mathrm{m}$ zone surrounding each lake with loon nests was less developed and cleared; had lower road density, less agricultural land, forest, and wetland; and contained more open water compared to the land cover surrounding the random non-nest site locations (Table 2).

\section{Ecoregional models}

The three physiographic ecoregions of New Hampshire differed in landscape composition for a number of the measured habitat types. Most notably, 
there was a higher proportion of human-altered landscape in the two ecoregions south of the White Mountains (ecoregions 2 and 3, Fig. 6). These two southern ecoregions have lakes surrounded by greater areas of developed land and higher road density, with higher measured values for conductivity and total phosphorous, and closer to human population centers (high-density residential areas and municipal community centers; Table 3, Fig. 6). Lakes in the Northern White Mountain ecoregion are found at higher elevations on average with greater areas of surrounding forested and wetland habitat, far from human population centers. The southwestern ecoregion, New HampshireVermont Upland, has greater areas of agricultural land and smaller lakes on average, distinguishing this ecoregion from the other two. The southeastern ecoregion, Southern New England Coastal Hills and Plain, has more open water surrounding the lakes, larger and deeper lakes with more shoreline perimeter, and more islands per lake on average compared to the two other ecoregions (Table 3).

The best approximating model designation within each data set has the highest $\mathrm{AIC}_{\mathrm{c}}$ weight, highest max-rescaled $\mathrm{R}^{2}$, and highest AUC classification value. For ecoregions 1 and 3 , the multiscale models had the highest $\mathrm{AIC}_{\mathrm{c}}$ weights and highest maxrescaled $R^{2}$ values compared to each of the single scale models within each respective ecoregion, suggesting that breeding habitat selection by loons is occurring at multiple scales. It is important to note that in the Northern White Mountain ecoregion (ecoregion 1), all five models (the four single-scale models and the multiscale model) have substantial empirical support (i.e., $\Delta_{\mathrm{i}} \mathrm{AIC}_{\mathrm{c}} \leq 2$ ), warranting a multimodel inference or model averaging approach, especially when a particular parameter (i.e., lake size) occurs in many of the candidate models (Burnham and Anderson 2002). This is also relevant for the models in the Southern New England Coastal Hills and Plain ecoregion (ecoregion 3), where all four of the single-scale models have many parameters in common. Therefore, model averaging was performed for all of the candidate models in ecoregion 1 and for the two highest ranking models in ecoregion 3 by weighting each model by its Akaike weight and combining into a composite averaged model for each of these ecoregions (Tables 4 and 5, respectively).

In ecoregion 2 (New Hampshire-Vermont Upland), the best approximating model was the model measured at the catchment scale (landscape features within $500 \mathrm{~m}$ of a lake). However, the multiscale model also had substantial empirical support. Thus, model averaging was performed with these two models to produce a composite averaged model for ecoregion 2 (Table 6).

\section{Statewide models}

The statewide models had a number of habitat characteristics in common describing breeding loon preferences at each scale: positive associations with distance to human population centers, water clarity, elevation, and lake size, and negative associations with road density and distance to nearby lakes with loon presence. The most parsimonious and best approximating model was the single riparian-scale model developed with environmental variables measured within the $150-\mathrm{m}$ zone of the lake (model 22, Table 7). This model describes loon preferences for clearer lakes nearby other lakes with loons, at higher elevations, with less surrounding road density, and further from human population centers. Notably, this was the only model within the statewide model set that contained the explanatory variable islands, and the only model with substantial empirical support based on information-theoretic statistics $\left(\Delta \mathrm{AIC}_{\mathrm{c}} \leq 2\right.$; Burnham and Anderson 2002$)$.

It is important to note that all of the final models across all three ecoregions, including the statewide models, achieved a high level of overall accuracy based on AUC values, which ranged from 0.914 to 0.989 , indicating that all of these models predict loon nest presence fairly well. The residuals of the best approximating single-scale and multiscale models showed no significant spatial correlation based on the Moran's Index scores. Given the weak spatial dependence of the residuals, we did not further investigate spatial autocorrelation.

\section{DISCUSSION}

\section{General habitat suitability model for Common Loon}

Based on information-theoretic statistics, the best approximating model among the statewide models is the single lake scale model describing the environment immediately surrounding the lake within a 150-m riparian buffer zone. Overall optimal breeding habitat for Common Loon across New Hampshire was identified as having the following 
Fig. 6. Proportion of developed land cover composition within 150- and 500-m zones surrounding lakes within each ecoregion. Blue diamond $=25 \%$ quartile, red square $=$ minimum value, green triangle $=$ median value, purple $\mathrm{x}=$ maximum value, blue $\mathrm{star}=75 \%$ quartile.
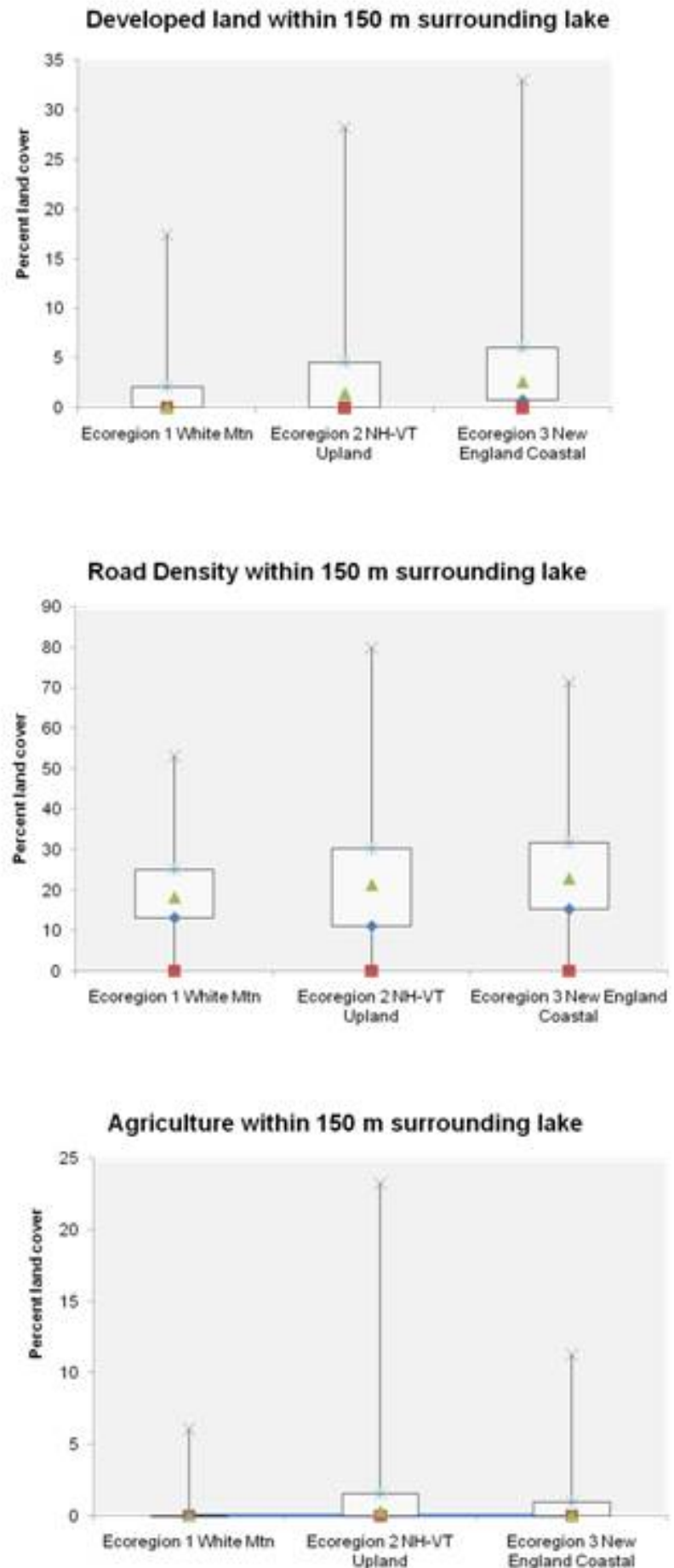
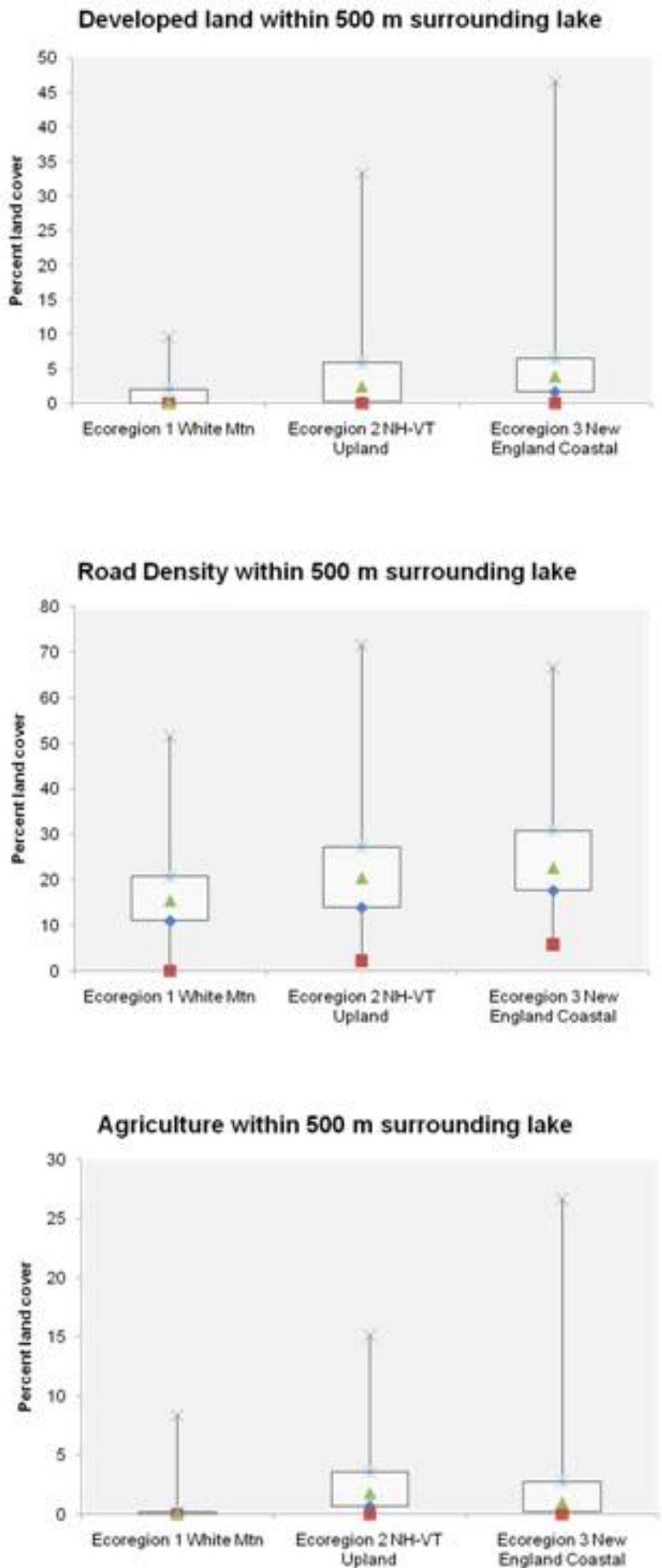
Table 3. Summary of lake habitat for the three ecoregions for selected explanatory variables. Means include both Common Loon nest presence and absence lakes.

\begin{tabular}{|c|c|c|c|c|c|}
\hline Habitat Variable & Ecoregion & Mean & SE & Min & Max \\
\hline Lake area (ha) & $\begin{array}{l}1 \\
2 \\
3\end{array}$ & $\begin{array}{c}137 \\
96 \\
303\end{array}$ & $\begin{array}{l}0.19 \\
0.10 \\
0.12\end{array}$ & $\begin{array}{l}10 \\
10 \\
12\end{array}$ & $\begin{array}{c}3262 \\
1819 \\
20,128\end{array}$ \\
\hline Lake perimeter $(\mathrm{km})$ & $\begin{array}{l}1 \\
2 \\
3\end{array}$ & $\begin{array}{l}13 \\
18 \\
42\end{array}$ & $\begin{array}{l}0.13 \\
0.07 \\
0.08\end{array}$ & $\begin{array}{l}0.19 \\
0.48 \\
0.15\end{array}$ & $\begin{array}{c}25,704 \\
8710 \\
3,019,995\end{array}$ \\
\hline Lake maximum depth $(\mathrm{m})$ & $\begin{array}{l}1 \\
2 \\
3\end{array}$ & $\begin{array}{c}10.1 \\
9.5 \\
12.1\end{array}$ & $\begin{array}{l}1.42 \\
0.80 \\
0.87\end{array}$ & $\begin{array}{l}1.3 \\
1.1 \\
1.5\end{array}$ & $\begin{array}{l}49.7 \\
55.5 \\
54.9\end{array}$ \\
\hline Islands (number/lake) & $\begin{array}{l}1 \\
2 \\
3\end{array}$ & $\begin{array}{l}2 \\
1 \\
4\end{array}$ & $\begin{array}{l}0.93 \\
0.25 \\
1.21\end{array}$ & $\begin{array}{l}0 \\
0 \\
0\end{array}$ & $\begin{array}{c}51 \\
17 \\
128\end{array}$ \\
\hline Elevation (m) & $\begin{array}{l}1 \\
2 \\
3\end{array}$ & $\begin{array}{l}465 \\
330 \\
145\end{array}$ & $\begin{array}{l}59.4 \\
28.9 \\
20.7\end{array}$ & $\begin{array}{c}155 \\
113 \\
5\end{array}$ & $\begin{array}{l}728 \\
722 \\
601\end{array}$ \\
\hline Lake flushing rate (number of turnovers/yr) & $\begin{array}{l}1 \\
2 \\
3\end{array}$ & $\begin{array}{l}21.3 \\
10.0 \\
34.1\end{array}$ & $\begin{array}{l}7.7 \\
2.2 \\
7.7\end{array}$ & $\begin{array}{l}0.3 \\
0.2 \\
0.2\end{array}$ & $\begin{array}{l}267 \\
176 \\
504\end{array}$ \\
\hline Water Clarity: Secchi depth(m) & $\begin{array}{l}1 \\
2 \\
3\end{array}$ & $\begin{array}{l}3.1 \\
3.8 \\
4.1\end{array}$ & $\begin{array}{l}0.22 \\
0.20 \\
0.18\end{array}$ & $\begin{array}{l}0.9 \\
0.8 \\
0.9\end{array}$ & $\begin{array}{c}9.7 \\
11.6 \\
10.2\end{array}$ \\
\hline Total phosphorous (mg/L) & $\begin{array}{l}1 \\
2 \\
3\end{array}$ & $\begin{array}{l}0.012 \\
0.012 \\
0.012\end{array}$ & $\begin{array}{l}<0.001 \\
0.001 \\
<0.001\end{array}$ & $\begin{array}{l}0.003 \\
0.001 \\
0.001\end{array}$ & $\begin{array}{l}0.038 \\
0.059 \\
0.052\end{array}$ \\
\hline Conductivity ( $\mu \mathrm{mhos} / \mathrm{cm})$ & $\begin{array}{l}1 \\
2 \\
3\end{array}$ & $\begin{array}{l}33.92 \\
48.21 \\
69.05\end{array}$ & $\begin{array}{l}2.71 \\
2.99 \\
4.77\end{array}$ & $\begin{array}{l}15.10 \\
16.51 \\
16.64\end{array}$ & $\begin{array}{l}112.60 \\
182.70 \\
306.00\end{array}$ \\
\hline Distance to loon lake (km) & $\begin{array}{l}1 \\
2 \\
3\end{array}$ & $\begin{array}{l}2.5 \\
3.2 \\
3.6\end{array}$ & $\begin{array}{l}0.35 \\
0.26 \\
0.46\end{array}$ & $\begin{array}{l}0.01 \\
0.01 \\
0.01\end{array}$ & $\begin{array}{l}13.6 \\
17.4 \\
28.7\end{array}$ \\
\hline Distance to community center $(\mathrm{km})$ & $\begin{array}{l}1 \\
2 \\
3\end{array}$ & $\begin{array}{l}8.5 \\
2.5 \\
2.9\end{array}$ & $\begin{array}{l}0.75 \\
0.02 \\
0.23\end{array}$ & $\begin{array}{l}0.01 \\
0.01 \\
0.01\end{array}$ & $\begin{array}{c}24.2 \\
6.6 \\
21.3\end{array}$ \\
\hline
\end{tabular}


Table 4. Summary of results for ecoregion 1 (Northern White Mountain) habitat models with their associated Akaike weights. $N=59$ lakes. Models with empirical support, i.e., $\Delta \mathrm{iAIC}_{\mathrm{c}} \leq 2$, are indicated in bold.

\begin{tabular}{|c|c|c|c|c|c|c|c|c|}
\hline Model & Scale & $R^{2}$ & $\mathrm{~K} \dagger$ & Log likelihood & $\mathrm{AIC}_{\mathrm{c}}$ & $\Delta_{\mathrm{i}} \mathrm{AIC}_{\mathrm{c}}$ & $\begin{array}{c}\text { Weight } \\
w_{\mathrm{i}}\end{array}$ & AUC \\
\hline 2 & Multiscale & 0.87 & 3 & -6.68 & 19.80 & $<0.001$ & 0.2444 & 0.989 \\
\hline 5 & Foraging & 0.73 & 2 & -7.86 & 19.93 & 0.14 & 0.2281 & 0.968 \\
\hline 3 & Catchment & 0.72 & 2 & -8.20 & 20.61 & 0.81 & 0.1627 & 0.951 \\
\hline 4 & Riparian & 0.72 & 2 & -8.26 & 20.74 & 0.94 & 0.1526 & 0.952 \\
\hline 6 & Nesting, 150-m radius & 0.76 & 2 & -8.46 & 21.14 & 1.34 & 0.1249 & 0.959 \\
\hline 1 & Global model & 0.86 & 5 & -5.36 & 21.85 & 2.06 & 0.0874 & 0.988 \\
\hline
\end{tabular}

Explanatory variables for each fitted model $\neq$

$\begin{array}{lll}2 & \text { Multiscale } & \text { lake size }(+), \text { open water 500N (+) } \\ \mathbf{5} & \text { Foraging } & \text { open water 500N }(+) \\ 3 & \text { Catchment } & \text { lake size }(+) \\ 4 & \text { Riparian } & \text { lake size }(+) \\ \mathbf{6} & \text { Nesting, 150-m radius } & \text { lake size }(+) \\ 1 & \text { Global model } & \text { elevation }(+), \text { lake size }(+), \text { clarity }(+), \text { open water 500N (+) }\end{array}$

Composite model: Nest presence $=-8.655+3.127($ lake size $)+1.570($ open water $500 \mathrm{~N})$

$\dagger \mathrm{K}$ indicates the total number of parameters, i.e., the intercept and explanatory variables.

$\ddagger(+)=$ positive association, $(-)=$ negative association, $\mathrm{L}=$ lake scale, $\mathrm{N}=$ nest scale.

characteristics: clear, higher elevation lakes with islands; further away from human population centers; with lower surrounding road densities; and with nearby lakes occupied by other loons. Water clarity has long been associated with loon habitat preference, and our results are consistent with previous studies (Vermeer 1973, McIntyre 1983, 1988, Blair 1992, Meyer 2006). The significance of the minimum-distance-to-nearest-lake-with-loonpresence metric supports anecdotal observations and published research describing loon natal dispersal. This biotic interaction metric describes the philopatric and conspecific attraction loons display and reveals the importance of the spatial configuration of lakes in the selection of loon breeding habitat (Strong et al. 1987, Evers 2001, Piper et al. 2006, 2008).

The unique habitat feature that distinguishes the best model among the statewide models is the explanatory variable islands, which indicates highquality breeding habitat for loons (Vermeer 1973, Jung 1991, McIntyre and Barr 1997, Piper et al. 2006, Evers 2007). Based on odds ratio estimates, islands and lake clarity were the most important factors distinguishing loon breeding habitat for the statewide data set (Table 8). The best statewide model also describes loon preferences for open 
Table 5. Summary of results for ecoregion 3 (Southern New England Coastal Hills and Plain) habitat models with their associated Akaike weights. $N=133$ lakes. Models with empirical support, i.e., $\Delta$ iAIC $_{c}$ $\leq 2$, are indicated in bold.

\begin{tabular}{lllcccccc}
\hline \hline Model & Scale & $R^{2}$ & $\mathrm{~K} \dagger$ & $\begin{array}{c}\text { Log } \\
\text { likelihood }\end{array}$ & $\mathrm{AIC}_{\mathrm{c}}$ & $\Delta_{\mathrm{i}} \mathrm{AIC}_{\mathrm{c}}$ & Weight $w_{\mathrm{i}}$ & $\mathrm{AUC}$ \\
\hline $\mathbf{1 4}$ & Multiscale & $\mathbf{0 . 7 2}$ & $\mathbf{6}$ & -32.84 & $\mathbf{7 8 . 3 5}$ & $<\mathbf{0 . 0 0 1}$ & $\mathbf{0 . 4 2 8 2}$ & $\mathbf{0 . 9 4 0}$ \\
$\mathbf{1 8}$ & Nesting & $\mathbf{0 . 6 9}$ & $\mathbf{4}$ & -35.30 & $\mathbf{7 8 . 9 2}$ & $\mathbf{0 . 5 7}$ & $\mathbf{0 . 3 2 2 0}$ & $\mathbf{0 . 9 3 1}$ \\
15 & Catchment & 0.66 & 5 & -35.65 & 81.78 & 3.43 & 0.0772 & 0.931 \\
16 & Riparian & 0.66 & 5 & -35.65 & 81.78 & 3.43 & 0.0772 & 0.931 \\
17 & Foraging & 0.66 & 5 & -35.65 & 81.78 & 3.43 & 0.0772 & 0.931 \\
13 & Global & 0.75 & 11 & -30.25 & 84.67 & 6.32 & 0.0181 & 0.949
\end{tabular}

Explanatory variables for each fitted model

\begin{tabular}{|c|c|c|}
\hline 14 & Multiscale & lake size $(+)$, elevation $(+)$, clarity $(+)$, distance to loon $(-)$, phosphorous $(-)$ \\
\hline 18 & Nesting & elevation $(+)$, lake size $(+)$, phosphorous $(-)$ \\
\hline 15 & Catchment & distance to loon $(-)$, elevation $(+)$, lake size $(+)$, clarity $(+)$ \\
\hline 16 & Riparian & distance to loon $(-)$, elevation $(+)$, lake size $(+)$, clarity $(+)$ \\
\hline 17 & Foraging & distance to loon $(-)$, elevation $(+)$, lake size $(+)$, clarity $(+)$ \\
\hline 13 & $\begin{array}{l}\text { Global } \\
\text { model }\end{array}$ & $\begin{array}{l}\text { leveloped } 150 \mathrm{~L}(-) \text {, open water } 150 \mathrm{~L}(+) \text {, road } 150 \mathrm{~L}(-) \text {, islands }(+) \text {, distance to loon }(-) \text {, } \\
\text { levation }(+) \text {, lake size }(+) \text {, phosphorous }(-) \text {, clarity }(+) \text {, open water } 500 \mathrm{~N}(+)\end{array}$ \\
\hline
\end{tabular}

Composite model: Nest presence $=-4.550+0.006$ (elevation $)+1.180$ (lake size $)+0.1714$ (clarity) -0.2183 (distance to loon) - 179.503 (phosphorus)

$\dagger \mathrm{K}$ indicates the total number of parameters, i.e., the intercept and explanatory variables.

$\ddagger(+)=$ positive association, $(-)=$ negative association, $\mathrm{L}=$ lake scale, $\mathrm{N}=$ nest scale.

water surrounding the lake (e.g., hydrological connectivity). Earnst et al. (2006) also found that Yellow-billed Loon in northern Alaska select breeding habitat based on landscape-scale features such as hydrological connectivity. The explanatory variable minimum-distance-to-human-populationcenter was featured at every scale in the statewide models, providing evidence that loons prefer to situate nests on lakes further from human disturbance. A lake habitat selection study for waterbirds in Canada also found that loons prefer lakes that are farther from human activity or have more forested land within a 500-m zone (Found et al. 2008).

\section{Effects of scale on Common Loon habitat associations}

Another of our objectives was to investigate whether Common Loon selects breeding habitat at multiple scales and to determine which scales are 
Table 6. Summary of results for ecoregion 2 (New Hampshire-Vermont Upland) habitat models with their associated Akaike weights. $N=130$ lakes. Models with empirical support, i.e., $\Delta \mathrm{iAIC}_{\mathrm{c}} \leq 2$, are indicated in bold.

\begin{tabular}{llccccccc}
\hline \hline Model & Scale & $R^{2}$ & $\mathrm{~K} \dagger$ & $\begin{array}{c}\text { Log } \\
\text { likelihood }\end{array}$ & $\mathrm{AIC}_{\mathrm{c}}$ & $\Delta_{\mathrm{i}} \mathrm{AIC}_{\mathrm{c}}$ & Weight $w_{\mathrm{i}}$ & $\mathrm{AUC}$ \\
\hline $\mathbf{9}$ & Catchment & $\mathbf{0 . 8 1}$ & $\mathbf{8}$ & -24.37 & $\mathbf{6 5 . 9 3}$ & $<\mathbf{0 . 0 0 1}$ & $\mathbf{0 . 6 7 5 7}$ & $\mathbf{0 . 9 7 1}$ \\
$\mathbf{8}$ & Multiscale & $\mathbf{0 . 8 3}$ & $\mathbf{1 0}$ & -23.10 & $\mathbf{6 8 . 0 6}$ & $\mathbf{2 . 1 3}$ & $\mathbf{0 . 2 3 3 1}$ & $\mathbf{0 . 9 7 3}$ \\
10 & Riparian & 0.75 & 6 & -28.72 & 70.11 & 4.18 & 0.0834 & 0.952 \\
7 & Global & 0.79 & 11 & -25.95 & 76.13 & 10.20 & 0.0041 & 0.963 \\
& model & & & & & & & 0.945 \\
11 & Foraging & 0.73 & 7 & -33.31 & 79.30 & 13.37 & 0.0008 & 0.930
\end{tabular}

Explanatory variables for each fitted model

9 Catchment open water 500L (+), road 500L (-), islands (+), $\mathrm{pH}(+)$, elevation (+), clarity (+), agricultural 500L (-)

8 Multiscale open water 150L (+), open water 500N (+), islands (+), clarity (+) road density 500L (-), road density $150 \mathrm{~N}(-)$, distance to loon $(-)$, forest $150 \mathrm{~N}(-)$, wetland $150 \mathrm{~N}(-)$

10 Riparian open water $150 \mathrm{~L}(+)$, islands (+), distance to loon (-), elevation (+), clarity (+)

$7 \quad$ Global open water $150 \mathrm{~L}(+)$, islands $(+)$, distance to loon $(-)$, elevation $(+), \mathrm{pH}(+)$, clarity $(+)$,

model agricultural 500L $(-)$, open water 500L $(+)$, road density $500 \mathrm{~L}(-)$, forest $500(-)$

$11 \quad$ Foraging $\quad$ open water 500N (+), agricultural 500N (-), clarity (+), elevation (+), lake size (+)

12 Nesting road density $150 \mathrm{~N}(-)$, forest $150 \mathrm{~N}(-)$, wetland $150 \mathrm{~N}(-)$, elevation $(+)$, lake size (+), flushing rate $(-)$

Composite model: Nest presence $=-22.579+3.179$ (islands) +1.047 (clarity) +0.004 (elevation) +0.287 (open water $150 \mathrm{~L})+0.405($ open water $500 \mathrm{~L})+0.1064($ open water $500 \mathrm{~N})+2.72(\mathrm{pH})-0.158($ road density $500 \mathrm{~L})-0.362$ (distance to loon) -0.314 (agricultural $500 \mathrm{~L})-0.086$ (forest $150 \mathrm{~N})-0.079($ wetland $150 \mathrm{~N})-0.065$ (road density $150 \mathrm{~N})$

$\dagger \mathrm{K}$ indicates the total number of parameters, i.e., the intercept and explanatory variables.

$\ddagger(+)=$ positive association, $(-)=$ negative association, $L=$ lake scale, $N=$ nest scale.

most important. Using information theoretic statistics, the multiscale models for two of the three ecoregions were designated the best approximating models and had substantial empirical support in all three ecoregions. Distinct differences are apparent when comparing models across ecoregions (Tables 4, 5, and 6). Loons in New Hampshire appear to be selecting breeding habitat differently based on physiographic ecoregion and at multiple scales. These differences may be a reflection of the occurrence of different environmental conditions and ranges of variables in the three different regions. In the Northern White Mountain ecoregion, loons are selecting breeding territories on the basis of lake 
Table 7. Summary of results for New Hampshire statewide habitat models with their associated Akaike weights. $N=322$ lakes. Models with empirical support, i.e., $\Delta \mathrm{iAIC}_{\mathrm{c}} \leq 2$, are indicated in bold.

\begin{tabular}{|c|c|c|c|c|c|c|c|c|}
\hline Model & Scale & $R^{2}$ & $\mathrm{~K}_{\dagger}$ & Log likelihood & $\mathrm{AIC}_{\mathrm{c}}$ & $\Delta_{\mathrm{i}} \mathrm{AIC}_{\mathrm{c}}$ & Weight $w_{\mathrm{i}}$ & AUC \\
\hline 22 & Riparian & 0.65 & 8 & -86.15 & 188.764 & 0.00 & 0.8315 & 0.926 \\
\hline 21 & Catchment & 0.64 & 8 & -88.43 & 193.315 & 4.55 & 0.0854 & 0.921 \\
\hline 23 & Foraging & 0.63 & 7 & -89.96 & 194.269 & 5.61 & 0.0504 & 0.919 \\
\hline 19 & Global model & 0.70 & 15 & -82.87 & 197.304 & 8.54 & 0.0115 & 0.941 \\
\hline 24 & Nesting & 0.62 & 7 & -91.92 & 198.196 & 9.54 & 0.0071 & 0.914 \\
\hline 20 & Multiscale & 0.65 & 8 & -93.65 & 203.769 & 15.01 & 0.0005 & 0.926 \\
\hline
\end{tabular}

Explanatory variables for each fitted model

22 Riparian $\begin{aligned} & \text { open water 150L (+), elevation (+), islands (+), clarity (+), distance to } \\ & \text { human population }(+) \text {, distance to loon }(-) \text {, road density } 150 \mathrm{~L}(-)\end{aligned}$

21 Catchment distance to loon (-), open water 500L (+), road density 500L (-), elevation (+), lake size $(+)$, clarity $(+)$, distance to human population $(+)$

$23 \quad$ Foraging

distance to loon $(-)$, open water $500 \mathrm{~N}(+)$, elevation $(+)$, lake size $(+)$, clarity $(+)$, distance to human population $(+)$

$19 \quad$ Global model

open water 500L $(-)$, road density $500 \mathrm{~L}(-)$, road density $150 \mathrm{~N}(-)$, open water $500 \mathrm{~N}(+)$, road density $150 \mathrm{~L}(-)$, open water $150 \mathrm{~L}(+)$, islands $(+)$, distance to loon $(-)$, elevation $(+)$, lake size $(+), \mathrm{pH}(+)$, phosphorous $(-)$, clarity $(+)$, distance to human population $(+)$

$24 \quad$ Nesting distance to loon $(-)$, road density $150 \mathrm{~N}(-)$, elevation $(+)$, lake size $(+)$, clarity $(+)$, distance to human population $(+)$

$20 \quad$ Multiscale distance to loon $(-)$, open water 500N $(+)$, road density 150L $(-)$, elevation $(+)$, lake size $(+)$, clarity $(+)$, distance to human population $(+)$

Statewide model: Nest presence $=-7.328+0.115$ (open water $150 \mathrm{~L})+0.001$ (elevation) +1.067 (islands) +0.595 (clarity) +0.211 (distance to human population) -0.233 (distance to loon) -0.033 (road density $150 \mathrm{~L}$ )

$\dagger \mathrm{K}$ indicates the total number of parameters, i.e., the intercept and explanatory variables.

$\ddagger(+)=$ positive association, $(-)=$ negative association, $\mathrm{L}=$ lake scale, $\mathrm{N}=$ nest scale.

size and the amount of open water surrounding the nest (e.g., island nest sites). In this ecoregion, there was no distinction between loon presence and absence lakes based on human-altered variables such as road density and developed land or water quality variables associated with human activities. The Northern White Mountain ecoregion has lower road densities surrounding the lakes and a less human-dominated landscape in general. Therefore, the loons' apparent selection based on a few lake morphological factors may be more a reflection of the general environmental conditions and lack of human-altered variables to select against. It is also interesting to note that loons in this northern ecoregion do not appear to be using the presence of other loons on nearby lakes as a habitat selection 
factor, as is the case in the two more southerly ecoregions.

The results for the Northern White Mountain ecoregion suggest that prior to human alteration of the landscape, loons may have chosen breeding habitat based primarily on lake morphological factors such as lake size and the amount of open water surrounding the nest. The catchment, riparian, foraging, and nest scale-based models within the Northern White Mountain ecoregion include information describing the selection of loon breeding habitat (Table 4). Three of these final fitted single-scale models had explanatory variables in common (i.e., lake size) and were combined in the multiscale model for this ecoregion to determine the best approximating model, given the data set, based on the model probability Akaike weights $w_{\mathrm{i}}$ (Table 4). However, using evidence ratios (Burnham and Anderson 2002) to compare the two best models, the best model (model 1) has only 1.9 times the weight of evidence relative to the second-best model (model 4). This relatively weak support for any of the models being the best model suggests that these models are good candidates for model averaging or multimodel inference. Model averaging increases parameter estimate precision and reduces bias associated with model selection, especially when all of the models have substantial support and are closely related, as in ecoregion 1 .

In the southwestern New Hampshire-Vermont Upland, loons appear to be avoiding human-altered landscapes such as those with high road density and greater areas of agriculture (Table 6). This region of New Hampshire contains the highest percentage of prime agricultural soils in the state and has experienced the highest amount of agricultural conversion to developed land in the state over the 5-yr period from 1997 to 2002 (Society for the Protection of New Hampshire Forests 2005). Within this ecoregion, loons are selecting lakes with more islands, higher water clarity, and more open water surrounding the lakes, and that are nearby other lakes with loons present. The catchment-scale model, describing features within a 500-m zone of the lake, best describes the data in this region (model 9 , Table 6); the only other model that has substantial empirical support for describing this data set is the multiscale model (model 8, Table 6). The catchment-scale model differs from the multiscale model by identifying positive associations of loons with $\mathrm{pH}$ (an indicator of fish/prey habitat) and lake elevation, and a negative association of loons with agricultural land within $500 \mathrm{~m}$ of the lake. Instead of relying on a single best model for this ecoregion, we used model averaging to combine these two highest ranking models to obtain robust estimates of model parameters, reduce model selection bias, and account for model selection uncertainty (Johnson and Omland 2004). Based on the model averaged results and using odds ratios to identify influential factors in this region, islands, $\mathrm{pH}$, and water clarity appear to be the most influential habitat features (Table 8).

Loons in the southeastern Southern New England Coastal Hills and Plain appear to be selecting breeding habitat similarly across all scales based on a few key elements: larger lakes at increasing elevations with lower levels of phosphorous nearby other lakes with loons (Table 5). Other studies have found that loons avoid lakes with higher phosphorous and primary productivity (Blair 1992), which can reduce water clarity. Total phosphorus, which is associated with anthropogenic activities, appears to be an important avoidance factor for loons selecting breeding habitat at multiple scales, based on the multiscale and nesting-scale models, which are the two highest-ranking models for this region. The two most influential factors in this region appear to be lake size and water clarity based on odds ratio estimates (Table 8).

The natural arrangement of lakes in New Hampshire, especially in the southeastern portion of the state (referred to as the Lakes Region), is of particular concern because this area has the fastest rate of human population change in New Hampshire. The entire state population is projected to grow by 358,000 between 2000 and 2025 , with an estimated $80 \%$ of that growth in the four southeastern counties of New Hampshire along the Interstate Highway 89 corridor and in the Lakes Region (Society for Protection of New Hampshire Forests 2005). Loons are responding to humaninduced pressures on these lakes and across the state by selecting against anthropogenic features such as road density, total phosphorous and conductivity, developed and agricultural lands, and human population centers.

\section{CONCLUSION}

Our results support the increasing evidence for multiscale habitat associations most commonly found in avian species (Gutzwiller and Anderson 
Table 8. Model averaged parameter estimates and odds ratio estimates with confidence intervals for ecoregional composite models and the statewide model. These parameters constitute the final averaged models for each ecoregion and may be used directly to predict Common Loon nest presence regionally and throughout the state of New Hampshire.

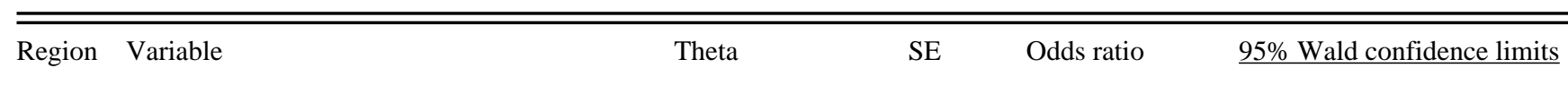

Ecoregion 1, Northern White Mountain

$\begin{array}{lrrrrr}\text { Intercept } & -8.655 & 0.704 & & & \\ \text { Lake size } & 3.127 & 0.096 & 6.935 & 0.934 & 51.509 \\ \text { Open water 500 nest } & 1.570 & 0.034 & 1.482 & 1.066 & 2.062\end{array}$

Ecoregion 2, New Hampshire-Vermont Upland

\begin{tabular}{|c|c|c|c|c|c|}
\hline Intercept & -22.579 & 10.485 & & & \\
\hline Islands & 3.179 & 1.120 & 18.045 & 2.760 & 117.970 \\
\hline Clarity & 1.047 & 0.349 & 2.952 & 1.500 & 5.810 \\
\hline Elevation & 0.004 & 0.002 & 1.004 & 1.000 & 1.007 \\
\hline Open water 150 lake & 0.287 & 0.136 & 1.383 & 1.153 & 1.658 \\
\hline Open water 500 lake & 0.405 & 0.1145 & 1.499 & 1.198 & 1.877 \\
\hline Open water 500 nest & 0.1064 & 0.0485 & 0.890 & 0.810 & 0.979 \\
\hline $\mathrm{pH}$ & 2.72 & 1.0139 & 15.195 & 2.083 & 110.844 \\
\hline Road density 500 lake & -0.158 & 0.064 & 0.880 & 0.789 & 0.983 \\
\hline Distance to loon lake & -0.3619 & 0.129 & 0.691 & 0.491 & 0.971 \\
\hline Agricultural 500 lake & -0.3143 & 0.1489 & 0.730 & 0.545 & 0.978 \\
\hline Forest 150 nest & -0.0856 & 0.0346 & 0.913 & 0.853 & 0.977 \\
\hline Wetland 150 nest & -0.0793 & 0.0346 & 0.920 & 0.859 & 0.985 \\
\hline Road density 150 nest & -0.0647 & 0.0286 & 0.927 & 0.877 & 0.980 \\
\hline
\end{tabular}

Ecoregion 3, Southern New England Coastal Hills and Plain

$\begin{array}{lrrrrr}\text { Intercept } & -4.550 & 0.217 & & & \\ \text { Elevation } & 0.006 & 0.001 & 1.004 & 1.000 & 1.009 \\ \text { Lake size } & 1.180 & 0.158 & 3.254 & 1.640 & 6.456 \\ \text { Clarity } & 0.1714 & 0.2835 & 1.187 & 0.681 & 2.069 \\ \text { Distance to loon lake } & -0.2183 & 0.124 & 1.000 & 1.000 & 1.000 \\ \text { Phosphorous } & -179.503 & 3.190 & <0.001 & <0.001 & <.001\end{array}$


New Hampshire Statewide

\begin{tabular}{|c|c|c|c|c|c|}
\hline Intercept & -7.3821 & 1.2467 & & & \\
\hline Open water 150 lake & 0.1150 & 0.0200 & 1.122 & 1.079 & 1.167 \\
\hline Elevation & 0.001 & 0.001 & 1.001 & 1.000 & 1.002 \\
\hline Islands & 1.0674 & 0.4210 & 2.908 & 1.274 & 6.637 \\
\hline Clarity & 0.5948 & 0.1503 & 1.813 & 1.350 & 2.434 \\
\hline Distance to population center & 0.2105 & 0.0797 & 1.234 & 1.056 & 1.443 \\
\hline Distance to loon lake & -0.2331 & 0.0732 & 0.792 & 0.686 & 0.914 \\
\hline Road density 150 lake & -0.0327 & 0.0148 & 0.968 & 0.940 & 0.996 \\
\hline
\end{tabular}

1987, Wiens et al. 1987, Saab 1999, Meyer et al. 2002, Graf et al. 2005, Kristan 2006, Lawler and Edwards 2006, Thogmartin 2007). The multiscale models within each ecoregion have substantial empirical support in describing breeding habitat, suggesting that Common Loon in New Hampshire is responding to environmental cues at scales ranging from broad catchment to finer riparian areas surrounding lakes as well as within lakes at the nesting scale. Loons also appear to be selecting habitat differently across the ecoregions based on the varying landscape conditions they encounter across New Hampshire. This differential selection of breeding habitat across ecoregions provides information for prioritizing conservation and focusing management efforts in New Hampshire. Conservation efforts in the northern ecoregion should be focused on preserving the relatively lower levels of human activity and disturbance pressures surrounding these northern lakes by preventing increases in road density and construction near lakes, especially within the immediate shoreline of larger lakes. Loon conservation and management activities in the two southern ecoregions should focus on reducing the effects of already existing human disturbances on water quality by mitigating sources of phosphorous that can also directly affect clarity. Other activities in these regions should include the prioritization for protection of highquality nesting habitat such as small islands and undisturbed areas of lakes, and preventing development in critical loon habitat. Our results suggest that conservation strategies for Common Loon should also consider environmental influences beyond the immediate lake or riparian scale, as the analysis demonstrates that loons are also responding to landscape-level and catchmentscale conditions surrounding lakes.

Responses to this article can be read online at: http://www.ace-eco.org/vol6/iss 1/art4/responses/

\section{Acknowledgments:}

We thank the many people who share our interest in Common Loon research and conservation. We appreciate the statistical assistance and advice of Dr. James Heltshe, and helpful advice from reviewers of early drafts, Drs. James Lake, Bryan Milstead, and Rick McKinney, as well as that of the anonymous reviewers who contributed to the final version of this manuscript. This is contribution number AED-10-048 of the Atlantic Ecology Division, National Health and Environmental Effects Research Laboratory, Office of Research and Development, U.S. Environmental Protection Agency. Although the research described in this contribution has been funded wholly by the U.S. Environmental Protection Agency, it has not been subjected to Agency-level review. Therefore, it does not necessarily reflect the views of the Agency. Mention of trade names, products, or services does not constitute endorsement or recommendation for use. 


\section{LITERATURE CITED}

Agresti, A. 1996. An introduction to categorical data analysis. Wiley, New York, New York, USA.

Alvo, R., D. J. T. Hussell, and M. Berrill. 1988. The breeding success of common loons (Gavia immer) in relation to alkalinity and other lake characteristics in Ontario. Canadian Journal of Zoology 66 (3):746-752.

Anderson, D. R. 2008. Model based inferences in the life sciences: a primer on evidence. Springer, New York, New York, USA. doi:10.1007/978-0-38 7-74075-1

Anderson, J. R., E. E. Hardy, J. T. Roach, and R. E. Witmer. 1976. A land use and land cover classification system for use with remote sensor data. Geological Survey Professional Paper 964. U. S. Geological Survey, Washington, D.C., USA.

Austin, M. 2007. Species distribution models and ecological theory: a critical assessment and some possible new approaches. Ecological Modelling 200(1-2):1-19. doi:10.1016/j.ecolmodel.2006.07.005

Barr, J. F. 1986. Population dynamics of the common loon associated with mercury-contaminated waters in northwestern Ontario. Occasional Paper Number 56. Canadian Wildlife Service, Ottawa, Canada.

Battin, J., and J. J. Lawler. 2006. Cross-scale correlations and the design of avian-habitat selection studies. Condor 108:59-70. doi:10.1650/0 010-5422(2006)108[0059:CCATDA]2.0.CO;2

Blair, R. B. 1992. Lake features, water quality and the summer distribution of Common Loons in New Hampshire. Journal of Field Ornithology 63(1):1-9.

Burgess, N. M., D. C. Evers, and J. D. Kaplan. 2005. Mercury and other contaminants in Common Loons breeding in Atlantic Canada. Ecotoxicology 14 (1-2):241-252. doi:10.1007/s10646-004-6271-0

Burnham, K. P., and D. R. Anderson. 2002. Model selection and multimodel inference: a practical information-theoretic approach. Second edition. Springer, New York, New York, USA.
Cox, D. R., and E. J. Snell. 1989. Analysis of binary data. Second edition. Chapman \& Hall, London, UK.

Cushman, S. A., and K. McGarigal. 2002. Hierarchical, multi-scale decomposition of speciesenvironment relationships. Landscape Ecology 17 (7):637-646. doi:10.1023/A:1021571603605

Cushman, S. A., and K. McGarigal. 2004. Hierarchical analysis of forest bird speciesenvironment relationships in the Oregon Coast Range. Ecological Applications 14(4):1090-1105. doi:10.1890/03-5131

Deppe, J. L., and J. T. Rotenberry. 2008. Scaledependent habitat use by fall migratory birds: vegetation structure, floristics, and geography. Ecological Monographs 78(3):461-487. doi:10.189 $\underline{0 / 07-0163.1}$

Desorbo, C. R., K. M. Taylor, D. E. Kramer, J. Fair, J. H. Cooley, Jr., D. C. Evers, W. Hanson, H. S. Vogel, and J. L. Atwood. 2007. Reproductive advantages for Common Loons using rafts. Journal of Wildlife Management 71(4):1206-1213. doi:10.2 193/2006-422

Driscoll, M. J. L., T. Donovan, R. Mickey, A. Howard, and K. K. Fleming. 2005. Determinants of wood thrush nest success: a multi-scale, model selection approach. Journal of Wildlife Management 69(2):699-709. doi:10.2193/0022-541X(2005)069[0699: DOWTNS]2.0.CO;2

Earnst, S. L., R. Platte, and L. Bond. 2006. A landscape-scale model of yellow-billed loon (Gavia adamsii) habitat preferences in northern Alaska. Hydrobiologia 567(1):227-236. doi:10.1007/s1075 0-006-0042-2

Edwards, T. C., Jr., G. G. Moisen, T. S. Frescino, and J. J. Lawler. 2003. Modeling multiple ecological scales to link landscape theory to wildlife conservation. Pages 153-172 in J. A. Bissonette and I. Storch, editors. Landscape ecology and resource management: linking theory with practice. Island Press, Washington, D.C., USA.

Environmental Systems Research Institute. 2009. ArcInfo, geographic information system (GIS) software. Version 9.1. Redlands, California, USA. 
Estrella, A. 1998. A new measure of fit for equations with dichotomous dependent variables. Journal of Business and Economic Statistics 16(2):198-205. $\underline{\text { doi: } 10.2307 / 1392575}$

Evers, D. C. 2001. Common Loon population studies: continental mercury patterns and breeding territory philopatry. Dissertation. University of Minnesota, St. Paul, Minnesota, USA.

Evers, D. C. 2007. Status assessment and conservation plan for the Common Loon (Gavia immer) in North America. BRI Report 2007-20. U. S. Fish and Wildlife Service, Hadley, Massachusetts, USA.

Evers, D. C., L. J. Savoy, C. R. DeSorbo, D. E. Yates, W. Hanson, K. M. Taylor, L. Siegel, J. H. Cooley, M. S. Bank, A. Major, K. Munney, B. Mower, H. S. Vogel, N. Schoch, M. Pokras, M. W. Goodale, and J. Fair. 2008. Adverse effects from environmental mercury loads on breeding common loons. Ecotoxicology 17(2):69-81. doi:10.1007/s10 646-007-0168-7

Fielding, A. H., and J. F. Bell. 1997. A review of methods for the assessment of prediction errors in conservation presence/absence models. Environmental Conservation 24(1):38-49. doi:10.1017/S03768929 $\underline{97000088}$

Fortin, M.-J., and M. R. T. Dale. 2005. Spatial analysis: a guide for ecologists. Cambridge University Press, Cambridge, UK.

Found, C., S. M. Webb, and M. S. Boyce. 2008. Selection of lake habitats by waterbirds in the boreal transition zone of northeastern Alberta. Canadian Journal of Zoology 86(4):277-285. doi:10.1139/Z0 7-137

Fraterrigo, J. M., and J. A. Downing. 2008. The influence of land use on lake nutrients varies with watershed transport capacity. Ecosystems 11 (7):1021-1034. doi:10.1007/s10021-008-9176-6

Freemark, K. E., D. Bert, and M. A. Villard. 2002. Patch-, landscape-, and regional-scale effects on biota. Pages 58-83 in K. J. Gutzwiller, editor. Applying landscape ecology in biological conservation. Springer, New York, New York, USA.
Gamma Design Software. 2001. GS+ geostatistics for the environmental sciences. Plainwell, Michigan, USA.

Garshellis, D. L. 2000. Delusions in habitat evaluation: measuring use, selection, and importance. Pages 111-153 in L. Boitani and T. K. Fuller, editors. Research techniques in animal ecology: controversies and consequences. Columbia University Press, New York, New York, USA.

Goldstein, H. 2003. Multilevel statistical models. Third edition. Hodder Arnold, London, UK.

Graf, R. F., K. Bollmann, W. Suter, and H. Bugmann. 2005. The importance of spatial scale in habitat models: Capercaillie in the Swiss Alps. Landscape Ecology 20(6):703-717. doi:10.1007/s1 0980-005-0063-7

Graham, M. H. 2003. Confronting multicollinearity in ecological multiple regression. Ecology 84:2809-2815. doi:10.1890/02-3114

Gutzwiller, K. J., and S. H. Anderson. 1987. Multiscale associations between cavity-nesting birds and features of Wyoming streamside woodlands. Condor 89:534-548. doi:10.2307/1368 $\underline{643}$

Hames, R. S., J. D. Lowe, S. Barker Swarthout, and K. V. Rosenberg. 2006. Understanding the risk to neotropical migrant bird species of multiple humancaused stressors: elucidating processes behind patterns. Ecology and Society 11(1): 24. [online] URL: http://www.ecologyandsociety.org/vol11/iss1/ $\underline{\operatorname{art} 24 / .}$

Hammond, C. A. M. 2008. A demographic and landscape analysis for common loons in northwest Montana. Thesis. University of Montana, Missoula, Montana, USA. [online] URL: http://etd.lib.umt.edu/ theses/available/etd-04242008-130448/.

Heimberger, M., D. Euler, and J. Barr. 1983. The impact of cottage development on Common Loon reproductive success in central Ontario. Wilson Bulletin 95(3):431-439.

Heinz, H., T. Waldhör, and M. Mittlböck. 2005. Careful use of pseudo $R$-squared measures in epidemiological studies. Statistics in Medicine 24 (18):2867-2872. doi:10.1002/sim.2168 
Hollister, J. W., P. V. August, J. F. Paul, and H. A. Walker. 2008. Predicting estuarine sediment metal concentrations and inferred ecological conditions: an information theoretic approach. Journal of Environmental Quality 37(1):234-244. doi:10.2134/ jeq2007.0105

Hosmer, D. W., and S. Lemeshow. 2000. Applied logistic regression analysis. Second edition. Wiley, New York, New York, USA. doi:10.1002/0471722 $\underline{146}$

Hutchinson, G. E. 1957. A treatise of limnology. Volume 1: geography, physics and chemistry. Wiley, New York, New York, USA.

Johnson, J. B., and K. S. Omland. 2004. Model selection in ecology and evolution. Trends in Ecology and Evolution 19(2):101-108. doi:10.1016/ j.tree.2003.10.013

Johnson, M. D. 2007. Measuring habitat quality: a review. Condor 109(3):489-504. doi:10.1650/8347.1

Johnston, C. A., and B. A. Shmagin. 2006. Scale issues in lake-watershed interactions: assessing shoreline development impacts on water clarity. Pages 297-313 in J. Wu, K. B. Jones, H. Li, and O. L. Loucks, editors. Scaling and uncertainty analysis in ecology: methods and applications. Springer, Dordrecht, The Netherlands.

Jung, R. E. 1991. Effects of human activities and lake characteristics on the behavior and breeding success of Common Loons. Passenger Pigeon 53:207-218.

Kamman, N. C., N. M. Burgess, C. T. Driscoll, H. A. Simonin, W. Goodale, J. Linehan, R. Estabrook, M. Hutcheson, A. Major, A. M. Scheuhammer, and D. A. Scruton. 2005. Mercury in freshwater fish of northeast North America: a geographic perspective based on fish tissue monitoring databases. Ecotoxicology 14(1-2):163-180. doi:10.1007/s1064 6-004-6267-9

Kristan, W. B., III. 2006. Sources and expectations for hierarchical structure in bird-habitat associations. Condor 108(1):5-12. doi:10.1650/0010-5422(2006) 108[0005:SAEFHS]2.0.CO;2
Kristan, W. B., III, and J. M. Scott. 2006. Hierarchical models for avian ecologists. Condor 108(1):1-4. doi:10.1650/0010-5422(2006)108[0001: HMFAE $] 2.0 . \mathrm{CO} ; 2$

Kuhn-Hines, A. 2008. A multiscale approach to breeding habitat model development and evaluation for the common loon, Gavia immer, in New Hampshire, USA. ETD Collection for University of Rhode Island. Paper AAI3346850. [online] URL: http://digitalcommons.uri.edu/dissertations/AAI3346850

Lawler, J. J., and T. C. Edwards, Jr. 2006. A variance-decomposition approach to investigating multiscale habitat associations. Condor 108 (1):47-58. doi:10.1650/0010-5422(2006)108[0047: AVATIM $] 2.0 . \mathrm{CO} ; 2$

Li, X., D. Li, Z. Ma, and D. Schneider. 2006. Nest site use by crested ibis: dependence of a multifactor model on spatial scale. Landscape Ecology 21 (8):1207-1216. doi:10.1007/s10980-006-0021-z

Loon Preservation Committee. 2004. Field collection protocol for surveying and managing Common Loons in New Hampshire. Loon Preservation Committee, Moultonborough, New Hampshire, USA..

Loon Preservation Committee. 2005. Meeting the challenge: thirty years of preserving loons and their habitats in New Hampshire. Loon Preservation Committee, Moultonborough, New Hampshire, USA.

Luck, G. W. 2002. The habitat requirements of the rufous treecreeper (Climacteris rufa). 1. Preferential habitat use demonstrated at multiple spatial scales. Biological Conservation 105(3):383-394. doi:10.10 16/S0006-3207(01)00222-1

MacKenzie, D. I. 2005. Was it there? Dealing with imperfect detection for species presence/absence data. Australian and New Zealand Journal of Statistics 47(1):65-74. doi:10.1111/j.1467-842X.20 05.00372.X

MacKenzie, D. I., J. D. Nichols, J. E. Hines, M. G. Knutson, and A. B. Franklin. 2003. Estimating site occupancy, colonization, and local extinction when a species is detected imperfectly. Ecology 84 (8):2200-2207. doi:10.1890/02-3090 
Martin, S. L., and P. A. Soranno. 2006. Lake landscape position: relationships to hydrologic connectivity and landscape features. Limnology and Oceanography 51(2):801-814. doi:10.4319/lo.2006 .51 .2 .0801

McGarigal, K., and B. J. Marks. 1995. FRAGSTATS: spatial pattern analysis program for quantifying landscape structure. General Technical Report PNW-GTR-351. U.S. Department of Agriculture Forest Service, Washington, D.C., USA.

McIntyre, J. W. 1983. Nurseries: a consideration of habitat requirements during the early chick-rearing period in common loons. Journal of Field Ornithology 54(3):247-253.

McIntyre, J. W. 1988. The Common Loon: spirit of northern lakes. University of Minnesota Press, Minneapolis, Minnesota, USA.

McIntyre, J. W., and J. F. Barr. 1997. Common loon, Gavia immer. In A. Poole and F. Gill, editors. The Birds of North America, 313. Academy of Natural Sciences of Philadelphia and American Ornithologists Union, Washington, D.C., USA.

Menard, S. 2002. Applied logistic regression analysis. Second edition. Sage Publications, Thousand Oaks, California, USA.

Meyer, C. B., S. L. Miller, and C. J. Ralph. 2002. Multi-scale landscape and seascape patterns associated with marbeled murrelet nesting areas on the U.S. west coast. Landscape Ecology 17 (2):95-115. doi:10.1023/A:1016574928706

Meyer, M. W. 2006. Evaluating the impact of multiple stressors on Common Loon population demographics-an integrated laboratory and field approach. EPA STAR Co-operative Agreement Number: R82-9085. Environmental Protection Agency, Washington, D.C., USA.

Meyer, M. W., D. C. Evers, J. J. Hartigan, and P. S. Rasmussen. 1998. Patterns of common loon (Gavia immer) mercury exposure, reproduction, and survival in Wisconsin, USA. Environmental Toxicology and Chemistry 17(2):184-190.

Meyer, M. W., and J. E. Woodford. 1996. Enhancing osprey (Pandion haliaetus) and common loon (Gavia immer) reproduction on impacted
Wisconsin waterways. Final report. U.S. Fish and Wildlife Service, Washington, D.C., USA.

Moran, P. A. P. 1950. Notes on continuous stochastic phenomena. Biometrika 37(1-2):17-23. doi:10.1093/biomet/37.1-2.17

Murtagh, P. A., and P. S. Pooler. 2006. Evaluating ecological indicators: lakes in the northeastern United States. Environmental Monitoring and Assessment 119(1-3):83-96. doi:10.1007/s10661-00 $\underline{5-9011-\mathrm{X}}$

New Hampshire Department of Environmental Services. 2005. Water quality data survey summary for New Hampshire lakes and ponds. New Hampshire Department of Environmental Services, New Hampshire, USA. [online] URL: http://des.nh. gov/organization/divisions/water/wmb/lakes/ trophic summary.htm.

New Hampshire Department of Environmental Services. 2006. Community center areas. New Hampshire Department of Environmental Services, New Hampshire, USA. [online] URL: http://www. granit.unh.edu/data/datacat/pages/communitycenterareas. pdf.

Newbrey, J. L., M. A. Bozek, and N. D. Niemuth. 2005. Effects of lake characteristics and human disturbance on the presence of piscivorous birds in northern Wisconsin, USA. Waterbirds 28 (4):478-486. doi:10.1675/1524-4695(2005)28[478: EOLCAH $] 2.0 . \mathrm{CO} ; 2$

Nocera, J. J., G. J. Forbes, and G. R. Milton. 2008. The relevance of local-scale relationships to habitat management and landscape patterns. Avian Conservation and Ecology - Écologie et conservation des oiseaux 3(1): 4. [online] URL: http://www.ace-eco.org/vol3/iss1/art4/.

Northeast Loon Study Work Group. 2008. [online] URL: http://www.briloon.org/science-and-conservation/ centers/NELSWG.php.

O'Brien, R. M. 2007. A caution regarding rules of thumb for variance inflation factors. Quality \& Quantity 41(5):673-690. doi:10.1007/s11135-006-9 $\underline{018-6}$

Patton, D. R. 1975. A diversity index for quantifying habitat 'edge'. Wildlife Society Bulletin 3:171-173. 
Penhollow, M. E., and D. F. Stauffer. 2000. Largescale habitat relationships of neotropical migratory birds in Virginia. Journal of Wildlife Management 64(2):362-373. doi:10.2307/3803234

Piper, W. H., C. Walcott, J. N. Mager III, M. Perala, K. B. Tischler, E. Harrington, A. J. Turcotte, M. Schwabenlander, and N. Banfield. 2006. Prospecting in a solitary breeder: chick production elicits territorial intrusions in common loons. Behavioral Ecology 17(6):881-888. doi:10.1093/beheco/arl021

Piper, W. H., C. Walcott, J. N. Mager, and F. J. Spilker. 2008. Nestsite selection by male loons leads to sex-biased site familiarity. Journal of Animal Ecology 77(2):205-210. doi:10.1111/j.1365-2656.2 $\underline{007.01334 . x}$

Rimmer, C. C. 1992. Common Loon, Gavia immer. Pages 3-30 in K. J. Schneider and D. M. Pence, editors. Migratory nongame birds management concern in the Northeast. U.S. Fish and Wildlife Service, Newton Corner, Massachusetts, USA.

Riitters, K. H., R. V. O’Neill, and K. B. Jones. 1997. Assessing habitat suitability at multiple scales: a landscape-level approach. Biological Conservation 81(1-2):191-202. doi:10.1016/S0006-3207(96)00145-0

Saab, V. 1999. Importance of spatial scale to habitat use by breeding birds in riparian forests: a hierarchical analysis. Ecological Applications 9 (1):135-151. doi:10.1890/1051-0761(1999)009[0135: IOSSTH $] 2.0 . \mathrm{CO} ; 2$

SAS Institute Inc. 2003. SAS 9.1. Cary, North Carolina, USA.

Scott, J. M., P. J. Heglund, M. L. Morrison, J. B. Haufler, M. G. Raphael, W. A. Wall, and F. B. Samson, editors. 2002. Predicting species occurrences: issues of accuracy and scale. Island Press, Washington, D.C., USA.

Society for Protection of New Hampshire Forests. 2005. New Hampshire's changing landscape: population growth and land use changes. Society for Protection of New Hampshire Forests. [online] URL: http://www.forestsociety.org/research/researchprojects.asp.
Soranno, P. A., K. E. Webster, K. S. Cheruvelil, and M. T. Bremigan. 2009. The lake landscape-context framework: linking aquatic connections, terrestrial features and human effects at multiple scales. Verhandlungen des Internationalen Verein Limnologie 30(5):695-700.

Sperduto, D. D., and W. F. Nichols. 2004. Natural communities of New Hampshire. New Hampshire Natural Heritage Bureau, Concord, New Hampshire, USA, and University of New Hampshire Cooperative Extension, Durham, New Hampshire, USA.

SPSS Inc. 1999. SPSS 10.0. Chicago, Illinois, USA.

Stauffer, H. B., C. J. Ralph, and S. L. Miller. 2004. Ranking habitat for marbled murrelets: a new conservation approach for species with uncertain detection. Ecological Applications 14(5):1374-1383. doi:10.1890/03-5068

Stein, B. A., and S. R. Flack. 1997. 1997 species report card: the status of U.S. plants and animals. The Nature Conservancy, Arlington, Virginia, USA. [online] URL: http://www.natureserve.org/li brary/1997speciesreportcard.pdf.

Strauss, B., and R. Biedermann. 2007. Evaluating temporal and spatial generality: How valid are species-habitat relationship models? Ecological Modeling 204:104-114. doi:10.1016/j.ecolmodel.20 $\underline{06.12 .027}$

Strong, P. I. V., and J. A. Bissonette. 1989. Feeding and chick-rearing areas of common loons. Journal of Wildlife Management 53:72-76. doi:10.2307/380 $\underline{1308}$

Strong, P. I. V., J. A. Bissonette, and J. S. Fair. 1987. Reuse of nesting and nursery areas by Common Loons. Journal of Wildlife Management 51:123-127. doi:10.2307/3801642

Taylor, K. M., and H. S. Vogel. 2000. New Hampshire report. Pages 110-113 in J. McIntyre and D. C. Evers, editors. Loons: old history and new findings. Proceedings symposium 1997 meeting. American Ornithologists Union North American Loon Fund, Holderness, New Hampshire, USA.

Thogmartin, W. E. 2007. Effects at the landscape scale may constrain habitat relations at finer scales. 
Avian Conservation and Ecology - Écologie et conservation des oiseaux 2(2): 6. [online] URL: URL: http://www.ace-eco.org/vol2/iss2/art6/.

Thogmartin, W. E., and M. G. Knutson. 2007. Scaling local species-habitat relations to the larger landscape with a hierarchical spatial count model. Landscape Ecology 22(1):61-75. doi:10.1007/s109 80-006-9005-2

Thompson, C. M., and K. McGarigal. 2002. The influence of research scale on bald eagle habitat selection along the lower Hudson River, New York (USA). Landscape Ecology 17(6):569-586. doi:10. 1023/A:1021501231182

Titus, J. R., and L. W. VanDruff. 1981. Response of the common loon to recreational pressure in the Boundary Waters Canoe Area, northeastern Minnesota. Wildlife Monographs 79:1-60.

Trocki, C. L., and P. W. C. Paton. 2006. Assessing habitat selection by foraging egrets in salt marshes at multiple spatial scales. Wetlands 26(2):307-312. doi:10.1672/0277-5212(2006)26[307:AHSBFE]2.0. $\underline{\mathrm{CO} ; 2}$

Turner, M. G. 2005. Landscape ecology: What is the state of the science? Annual Review of Ecology, Evolution, and Systematics 36:319-344. doi:10.114 6/annurev.ecolsys.36.102003.152614

Tyre, A. J., B. Tenhumberg, S. A. Field, D. Niejalke, K. Parris, and H. P. Possingham. 2003. Improving precision and reducing bias in biological surveys: estimating false-negative error rates. Ecological Applications 13(6):1790-1801. doi:10.1890/02-5078

Vermeer, K. 1973. Some aspects of the nesting requirements of common loons in Alberta. Wilson Bulletin 85:429-435.

Wiens, J. A. 1989. Spatial scaling in ecology. Functional Ecology 3:385-397. doi:10.2307/2389612

Wiens, J. A. 2002. Riverine landscapes: taking landscape ecology into the water. Freshwater Biology 47(4):501-515. doi:10.1046/j.1365-2427.2 $\underline{002.00887 . x}$

Wiens, J. A., J. T. Rotenberry, and B. van Horne. 1987. Habitat occupancy patterns of North
American shrubsteppe birds: the effects of spatial scale. Oikos 48:132-147. doi:10.2307/3565849

Wilcove, D. S., D. Rothstein, J. Dubow, A. Phillips, and E. Losos. 1998. Quantifying threats to imperiled species in the United States. Bioscience 48:607-615. doi: $10.2307 / 1313420$

Wu, J. 2004. Effects of changing scale on landscape pattern analysis: scaling relations. Landscape Ecology 19(2):125-138. doi:10.1023/B:LAND.000 $\underline{0021711.40074 . \mathrm{ae}}$ 